ANL-7811

DR./8S/ ANL-7811

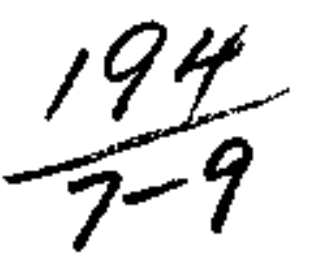

CONT-701215. that

CONFERENCE ON THE ESTIMATION OF

LOW-LEVEL RADIATION EFFECTS

IN HUMAN POPULATIONS

December 1970

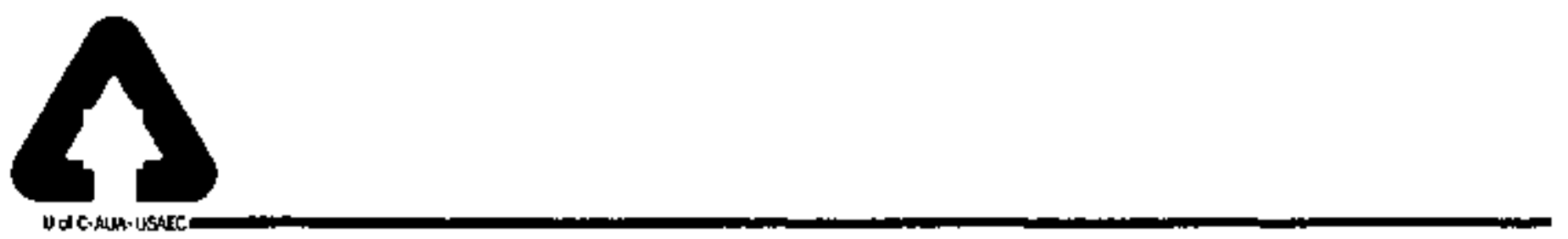

ARGONNE NATIONAL LABORATORY, ARGONNE, ILLINOIS 


\section{DISCLAIMER}

This report was prepared as an account of work sponsored by an agency of the United States Government. Neither the United States Government nor any agency Thereot, nor any of their employees, makes any warranty, express or implied, or assumes any legal liability or responsibility for the accuracy, completeness, or usefulness of any information, apparatus, product, or process disclosed, or represents that its use would not infringe privately owned rights. Reference herein to any specific commercial product, process, or service by trade name, trademark, manufacturer, or otherwise does not necessarily constitute or imply its endorsement, recommendation, or favoring by the United States Government or any agency thereof. The views and opinions of authors expressed herein do not necessarlly state or reflect those of the United States Government or any agency thereof. 


\section{DISCLAIMER}

Portions of this document may be illegible in electronic image products. Images are produced from the best available original document. 
The facilities of Arponne National Laboratory are owned by the United States Government. Undet the terms of a contract (W-31-109-Eng-38) between the $U$ 5. Atomic Energy Commssion, Argonne Univergitses Agsociation and The Untversity of Chicago, the University employo the staff and operates the Laboratory un accordance with polncies and programs formulated, approved and reviewed by the Association.

\section{MEMBERS OF ARGONNE UNIVERSITIES ASSOCIATION}

The Unversity of Arizona Carnage-Mellon Unver:tty Case Western Regerve Unuversity The University of Chicago Univer sity of Cincingats Illınois lostuture of Technology University of Imrnows lndiana Univeraity lowa State Uriveraity The tgiversity of Iowa
Kanaz: State Univereity The Uraveraity of Kansas

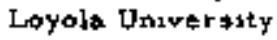
Marquette University Michigan State Univeroity The Univeraity of Michigan Unrvergily of Minnesote Univeryity of Miatipu Northwattar Untuerasty Unuversity of Notre Dame
The Oho State Unuerssty

Ohio Univeretty

The Perneylyanta State University

Purdue University

Saint Louss University

Southern Ilbnois University The University of Texas at Austin Washengtan University Wayne State University The Unuversity of Wisconsin

\section{NOTICE}

This report was prepared as an account of wotk sponsored by the United States Government Nerther the United States nor the United States Atome Energy Commussion, nor any of thetr employee 9 , nor any of thenr contractors, subcontractors, or their employes, makes any warranty, express or implied, or assumes any legal ixabnluty or responsibulity for the accuracy, completenets or utefulness of any uformation, apparatus, product or process disclosed, or represents that its use would not ufringe privately-owned rights

Printed in the United States of America

Avalable from

National Techrucal Information \$ervice

d \$ Department of Commerce 52 BS Part Royal Road

Sprungfield, Virginia ZZ15I

Price Pranted Gopy $\$ 300$, Microische $\$ 095$ 


\section{ARGONNE NATIONAL LABORATORY}

9700 South Cass Avenue

Argonne, tllunos 60439

\section{CONFERENCE ON THE ESTIMATION OF \\ LOW-LEVEL RADIATION EFFECTS IN HUMAN POPULATIONS}

Argonne National Laboratory

December 7, 8, and 9, 1970

\section{Conyentr:}

George A. Sacher, Argonne National Laboratory John B. Storer, Ouk Ridge National Laboratory

Editor.

George A. Sacher

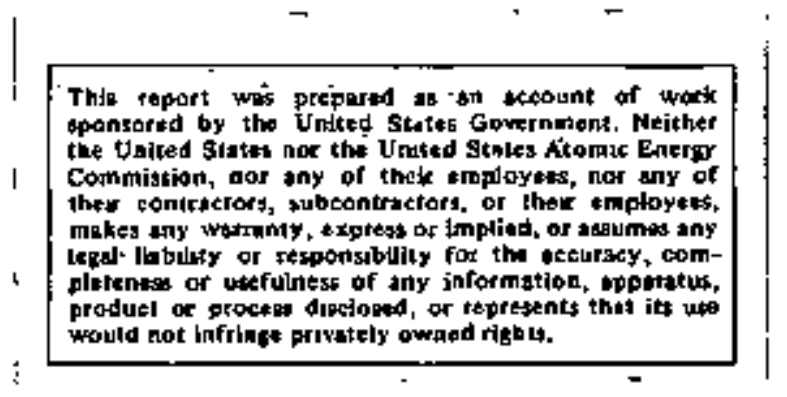

May [97] 


\section{FOREWORD}

The sometumes acrumonıous public discussions in 1969 and 1970 about the adequacy of existing 1CRP, NCRP and FRC guidelunes on exposure of human populatıons led to an awiteness among radiobiologists of the need for a searching reexamunation of the present stuation in the radiobiology of low-level exposure The two conveners of the present Conference first discussed the desirabulsty of such a conference in April, 1970 , and proposed it at the May, 1970, meeting of the Executive Committee of the North American Late Elfects Group The comrruttee members were cognizant of the semousness of the posstion, and voted to endorse the proposal They aiso Iecommended to the Radiatıon Research Society that a plenary sympostum on the formulation of exposure guldelines be held at the May, 197] mesting of the Society in Bosion It can be noted parenthelicalsy that the Society accepted the recommendation

Dr W K Sinclatr. Director of the Division of Biological and Medical Research, Argonne Nalional Laboratory, agreed to be sponsor and host for the Conference The travel expenses of most of the participanls were pasd by their own institutions The Division of Biology and Medicine, U S Atomic Energy Commission, made a grant, admunstered by the American lnstitute of Bıological Scıences, to support the travel of some participants from universities who had no other source of travel funds

The contributions from the following instituuons were based on research supported un whole or in pari by the US Atomic Energy Commıssion Argonne Natıonal Laboratory. Battelie-Northwest Laboratory, Brockhaven Natıonal Laboratory, Unwersily of Calıforma, Lawrence Radiatıon Laboratory, University of Calıfornia, Davis, Unyersity of Califormua, San Francisco, University of Chicago, Columbia University, New York University Medical Cenier, Oak Rudge National Laboratory, University of Rochester. University of Utah, and Unversity of Wisconsur

The plan was to convene a smal] round-table conference of about two dozen active participants and a few observers from intere sled agencies The uniual invitations were accepted almost unanumously, and then the need to achueve satusfactory balance and representation led to additions to the lsst, until the Conference convened with a roster of 44 participants and 10 observers It was still possible to adhere to the original symmetrucal plan. which gave all participants an equal role in the discussions, but only at the price of uncomfortably short tume allowances for the presentations The good will and dialectical skıll of the speakers overcame this difficulty, and there was a stumulating discussion of a wide range of topics and viewpoints

It was considered desirable to produce a concise report of the proceedings of the Conference, and the following procedure was adopted Each participant brought to the meeting a brief position paper in which he assessed the present status of the problem of low-level effects from the standpoint of his own discapline and research Interests, and proposed poientially productive directions of research These statements were also the framework of his aral participation One or two rapporteurs were appounted for each session and instructed to bring in brief accounts of the sessions, with emphasis on recording the trend of the free discussion The postuon statements and rapporteur accounts make up the first and second sections of this report

The sesson chairmen were empowered to appoint ad hoc commitiess to report on specific topics that arose during the discussions One such report was requested, and il appears at the end of the first section Several conferees dustribuled prepronts of full-length papers, or supplementary extended posstion statements These contrbutuons are cited at the end of the first section

There was a meeting of the entire group, particspants and observers, as a committee of the whole on the final morning of the Conference This is reported briefly in the third section of the report, which also contains an overyew and critique of the Conference as a whole, prepared at the request of the conferes

For convenience in reference, the position papers and rapporteurs' accounts are pnited on tunted paper.

We acknowledge with gratutude the assistance of Mrs Dorothy Carlson and Mrs Miriam Holden, of the Argonne conference secretaruat, for efficient arrangements, Mis Margaret Fieldhouse, of Argonne's Technical Publscations Divssion, for editorial assistance, Mr Edward J Bauser, Executive Director, Joint Congressional Committee on Atomic Energy, for copres of JCAE publications and bibluographic assistance

George A Sacher

John B Storer

May, 1971 


\section{TABLE OF CONTENTS}

FOREWORD . . . . . . . . . . . . . . . . . . . . . . . . . . . . . . . i

CONFERENCE PARTICIPANTS , . . . . . . . . . . . . . . . . . . . . . , vi

CONFERENCE PROGRAM . . . . . . . . . . . . . . . . . . . . . . . . . . ix

POSITION PAPERS

Mannmalian Radiobiology

SYSTEMIC AND PHYSICAL FACTORS

POSITION STATEMENT ON SYSTEMIC AND PHYSICAL FACTORS ． . . . . . . . . . . . I

Pielro Melallı and Govanni $\left.S_{1}\right]$ in

POSITION STATEMENT ON SYSTEMIC AND PHYSICAL FACTORS $\quad$. , . . . . . . . . . 2

J. B. Siprer

RELEVANCE OF ANIMAL EXPERIMENTATION TO ESTIMATINC SOMATIC EFFECTS OF

LOW-LEVEL RADIATION IN HUMAN POPULATIONS . . . . . . . . . . . . . . . 2

H. F., Walkurg, Jr.

IMPLICATIONS OF DOSE RATE AND DOSE FRACTIONATION ． . . . . . . . . . . . 3

D. C. Willhoit

LATE EFFECTS OF RADIATION , . . . . . . . . . . . . . . . . . . . . . . 4

J. M. Yuhas

CARCINOGENESIS

CONSIDERATION OF CARCINOGENIC MECHANISMS IN THE PREDICTION OF

LOW-LEVEL RADLATION EFFECTS

A. M. Brues

THE CARCINOGENIC ACTION OF SMALL DOSES OF DIFFERENT IONIZING RADIATIONS ～. S

G. W. Barendsen, J. J. Eroerse, and C. F. Hollander

THE RELEV ANCE OF MORTALITY AND CARCINOGENESIS AS CRITERLA FOR

ASSESSMENT OF LOW-LEVEL RADIATION EFFECTIVENESS ， . . . . . . . . . . . . 6

D. J. Mewissen

LARGE ANIMAL STUDIES

THE APPLICATION OF THE LOGISTIC DOSE-RESPONSE SURF ACE IN EVALUATION OF

TUMOR INCIOENCE FOLLOWING EXPOSURES TO INTERNAL ENITTERS . . . . . . . . . 7

Marvu Goldman, L $\mathbf{S}$. Rosenblatt, L. K. Bustad, and N. H. Hetherington

DOSE-RESPONSE RELATIONSHIPS IN THE INDUCTION OF BONE SARCOMAS BY

RADLONUCLIDES . . . . . . . . . . . . . . . . . . . . . 8

C. W. Mays

ANIMAL STUDIES TO ESTIMATE LOW-LEVEL RADLATION EFFECTS IN HUMAN

POPULATIONS

S. M. Michaelson

ESTIMATION OF LOW-LEVEL RADIATION EFFECTS OF INHALED PLUTONIUM AND

URANIUM MINE AIR CONTAMINANTS IN HUMAN POPULATIONS . . . . . . . . . . . 10

J. F. Park

TISSUES AND CELLS IN VIVO

LATE RADIATION EFFECTS: COMMENTS ON IN VIVO SYSTEMS . . . . . . . . . . . . 11

E. J. Ainsworth

RELATIVE IMPORTANCE AMONG VARIOUS LOW-LEVEL EFFECTS IN MAN ， . . . . . . 11

J. L. Bateman

IN VIVO MAMMALIAN RADIOBIOLOGY AND SPECIFIC SYSTEMS ， , , , . . . , , , 12

E. B. Darden, Jr.

SOME ASPECTS OF ANIMAL AND CELL POPULATION EXPERIMENTS ， ， . . . . . . . 13

R. J. M. Fry 
Genetics and Cellular Radiobialogy

GENETICS

GENETIC EFFECTS OF LOW-LEVEL RADATION IN HUMAN POPULATIONS. STUDIES

WITH DROSOPHLA MELANOGASTER . . . . . . . . . . . . . . . . . . . . . 13

Seymovi Abrahamson

A PROPOSAL TO ESTABLISH VITAL STATISTICAL MONITORING SAMPLES IN SELECTED

GEO-ECONOMIC REGIONS OF THE CONTINENTAL UNITED STATES TO DETECT

POTENTIAL DETRIMENTAL EFFECTS OF LOW-LEVEL ENYIRONMENTAL HAZARDS ． . . 14

Douglas Grahn

CYTOGENETICS

CYTOGENETICS . . . . . . . . . . . . . . . . . . . . . 15

A. B. Reiskin

STATEMENT ON CYTOGENETIC EFFECTS OF LOW-LEVEL RADIATION ， . . . . . . . 16

Sheldon Wolff

CELLULAR RADIATION BIOLOGY

CELL CULTURE STUDIES RELATIVE TO MUTATION AND TRANSFORMATION ， . . . . 17

M. M. Elkind

CELLULAR RADIOBIOLOGY AND LOW-LEVEL RADIATION EFFECTS ON HUMANS ． ， . . 17

W. K. Sinclair

IN VITRO STUDIES OF GENETIC AND CARCINOGENIC EFFECTS OF RADIATION ， ， ， , 19

G. F. Whitmore

Human Epidemiology

FOLLOW.UP OF EXPOSED POPULATIONS

HUMAN EPIDEMIOLOGY , . . . , , , . . . . . . . . . . . . . . 19

R. E. Albert

THE EFFECTS OF RADIATION ON THE FETUS . . . . . . . . . . . . . . . . 20

M. L. Griem

LOWLEVEL RAOHATION EFFECTS IN HUMAN POPULATIONS . . . . . . . . . . . . 21

L. H. Hemplemann

SOME RECOMMENDATIONS FOR EPIDEMIOLOGICAL STUDIES ， ， ， ， , , . . . . . 21

E. L. Saenger

EPIDEMIOLOGY OF ENVIRONMENTAL EFFECTS

WHAT CAN BE LEARNED ABOUT LOW-LEVEL RADIATION EFFECTS FROM THE

RADIUM CASES? , . . . , , , . . . . . , , , . . . . . . 22

R. E. Rowland

EPIDEMIOLOGY OF ENVIRONMENTAL EFFECTS . . . . . . . . . . . . . . . . 23

P. E. \$artwell

EPIDEMIOLOGY OF ENVIRONMENTAL EFFECTS . . . . . . . . . . . . . . . , 24

Raymond Seltser

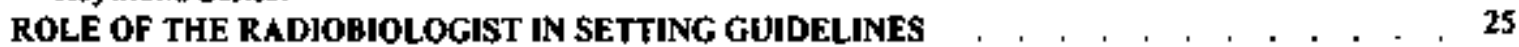

A. R. Tamplin

DOSIMETRY STANDARDIZATION-COOPERATION IN LATE EFFECTS RESEARCH IN

J. J. Broerse

A STATEMENT ON LOW-LEVEL EFFECTS IN HUMAN POPULATIONS ～. . . . . . . . . . 26

H. H. Rossi

THE DOSE-EFFECTIVENESS FUNCTION (DEF). DEFINITION, DATA, AND A

CYTOGENETIC MODEL

G. A. Sacher

Exposure Guidelines: The Process

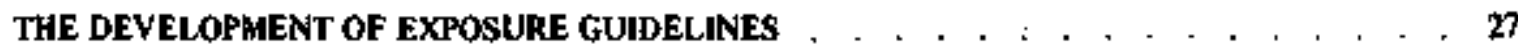

Lauriston Taylor

Chairnan's Committee Report

ON THE DOURLING DOSE CONCEPT . . . . . . . . . . . . . . . . . . . . . 28

C. W. Mays 


\section{RAPPORTEURS' ACCOUNTS}

\section{Mammalian Radiobiology} SYSTEMIC AND PHYSICAL FACTORS , . , . . . . . . . , . . . . . . . . . . . 31

J. B. Storer and J. M. Yuhas CARCINOGENESIS . . . . . . . . . . . . . . . . . . , 31

A. M. Brues and C. F. Hollander

LARGE ANIMAL STUDIES . . , . . , , , . . . . . , , . . . . . . . . . 32

Marvin Goldman and S. M. Michaelson

TISSUES AND CELLS IN VIVO ， . . . . . . . . . . . . . . . . . . . . . . , 32

E. B. Darden, Jr. and R. J. M. Fry

Genetics and Cellular Radiobiology

GENETICS

Sey mour Abrahamson

CYTOGENETICS

A. B. Reiskın

CELlULAR Radiation BIOLOGY.

G. F. Whitmare

Human Eptdemiology

FOLLOW-UP OF EXPOSED ROPULATIONS , . , , , , , , , , , . . . 35

G. W. Beebe, M. L. Griem, and E. L. Saenger

EPIDEMIOLOGY OF ENVIRONMENT AL EFFECTS . . . . . . . . . . . . . . . . . 36

P. E. Sartwel!

Physies and Models . . . . . . . . . . . . . . . . . . . . . . . . . . . . . . 37

J. J. Bioerse

MEETING AS A COMMITTEE OF THE WHOLE , . . . . . . . . . . . . . . . . . . . . . . . . . . 39

OVERVIEW AND CRITLQUE OF THE CONFERENCE . . . . . . . . . . . . . . . . . . . . . . . 4 L

W. K. Sinclaur, R. E. Rowland, and G. A. Sacher 


\section{CONFERENCE PARTICIPANTS}

ABRAHAMSON, Seymour

The University of Wisconsin

Depariment of Zoology

1117 West Johnson Street

Mtodison, Misconsin S3706

ADLER, Howard I.

Oak Ridge National Laborafory

Oak Ridge, Tennessee

AINSWORTH, E. John

Argonne National Laboratory

ALBERT, Roy E.

New York University Medical Center Environmental Medicine Dept. 550 First Avenue

New York, New York 10016

BATEMAN, John $L$.

Brookhaven National Labarafory

Medical Deparment

Upron, New York 1 I973

BEEBE, Gilbert W,

National Acrdemy of Sciences

Notional Research Cotuncit

Medical Sciences-Follow-up Agency 2101 Constitution Avenue, $N_{+} \mathbf{W}$.

Washington, D. C. 20418

BROERSE, J. J.

Radiobiological Instiftute, TNO

ISI Lange Kleiweg

Rijswifk, $Z H$, The Netherlands

BRUES, Austin $M$.

Argonne National Laboratory

BUSTAD, Leo K.

University of Califomia

Radiobiology Laboratory

Davis, Califomia 95616

CALDECOTT, Richard S.

University of Minnesote

Depariment of Biology

123 Snyder Hall

St. Paul, Minnesota
CROW, Janes $F$.

The University of Wisconsin

Genetics Building

Madison, Wisconsin $\$ 3706$

DARDEN, E. B.

Oak Ridge National Leboratory

Biology Division

Post Office Box $Y$

Oek Ridge, Tennessee 37830

DUFFIELD, Robert B.

Argonnte National Laboratory

EDINGTON, Charles W.

U.S. Atomic Energy Commission Dixision of Biology and Medicine Washington, D. C.

ELKIND, M. M.

Brookhaven National Laboratory

Department of Biology

Upton, New York 11973

FRIEDELL, Hy mer $\mathbf{L}$.

Case Westem Reserve Universiry

University Hospitals

Department of Radiology

2065 Adelbent Road

Cleveland, Ohio 44J06

FRY, R. J. Michael

Argonne National Laboratory

GOLDMAN, Marrin

University of Califormia

Radiobiology Laboratory

Davis, Colifomia 95616

GRAHN, Douglas

Argonne National Laboratory

GRJEM, Melvin L.

The University of Chicago Clinics

Depurtment of Radiology

959 East 59 th Street

Chicato, litinots 6063 ? 
HARVEY, Ejmer B.

International Atomic Energy Agency

Research and Isotopes Department

11/3 Kaemtriering

A.10ll Vienno, Austria

HEMPELMANN, Louis $\mathrm{H}$.

Strong Memorial Hospital

260 Crittenden Boulevard

Rochester, New York 14620

HOLDER, Lawrence E.

Western Environmentel Radiation Laboratory

Post Office Box 15027

Las Vegas, Newada 89114

HOLLANDER, Carel F.

Experimental Gerontology Unit, TNO

15/ Lange Kleiweg

Rijswijk, ZH, The Netherlands

MAYS, Charles $W$.

University of Uiah

Radiobiology Deportment

Salt Lake City, Utah 84112

MEW'SSEN, Dieudonnt J.

The University of Chicago

Department of Radiology

950 East 59th Street

Chicego, Itinois 60637

MICHAELSON, SOL M.

Universiry of Rochester

Department of Radiation Biology

and Biophysics

400 Elmwood Avenue

Rochester, New York 14620

MILLER, \$. A.

Argorne National Laboratory

MILLS, William A.

Envitonmental Protection Agency

Research Division

Office of Research \& Monitoring

5600 Fishers Lane

I Rockville, Maryland 20852

(Formerly with DHEW-PHS Burean of Radiological Health/

PALMITER, Claire C.

Environmental Protection Agency

Division of Criterin and Standards

Office of Radiation Programs

5600 Fishers Lone

Rockville, Moryland 20852

fFormerly with Federal Radiation

Councily
PARK, James F.

Bartelle-Northwest Laboratory

Biology Department

Post Office Box 999

Richland, Washingron 99352

RE]SKIN, Allan B.

University of Connecticut Health Center

McCook Division

2 Holcomb Street

Hattord, Connecticut 0600I

ROSENBLATT, LeON \$.

University of Calfomie

Radiobiology Labomtory

Dayis, California

Mailing Address: 1831 Delaware Street

Berkeley, Califormis 94703

ROSSI, Harald H.

Columbia University

College of Physicians and Surgeons

630 West 168th Street

New York. New York 10032

ROWLAND, Robett E.

Argonne National Laboratory

RUST, John H.

The Universily of Chicago

Departments of Rodilology \& Pharmecology

950 East 58 th Street

Chicago, /linois 60637

SACHER, George A

Argonne National Laboratory

SAENGER, Eugene L.

University of Cincintat

College of Medicite

Department of Radiology

Radioisotope Laborafory.General Hospital

Cincinnati, Ohio 45229

SARTWELL, Philip E.

Johns Hopkins School of Hygtene \& Public Hedth Depariment of Epidemiology

615 North Wolfe Street

Bolsimore, Maryland 21205

SELTSER, Raymond

Johns Hopkins School of Hygiene \& Public Health

Depertment of Epidemiology

615 North Wolfe Street

Balimore, Maryland 21205 
SILINI, Giowanni

$C, N, E, N$.

Laborataria di Radiabiologia Animale

$V_{i}$ Anguillorese

S. Maria di Galeria (Roma), Italy 00060

SINCLAIR, Warren $\mathrm{K}$.

Argonne National Laboratory

STAPLETON, George E.

U.S. Alomic Energy Commission

Division of Biology \& Medicine

Washington, D. C. 20545

STORER, John B.

Oak Ridge National Laboratory

Biology Divition

Post Office Box $Y$

Oak Ridge, Tennessee 37830

TAMPLIN, Arthur R.

University of California

Lawrence Radiation Labaratory

Livermore, California

TAYLOR, Launston S.

National Acadenyy of Sciences

2101 Constintion A venue, $N, W$.

Washington, D. C. 20418

VOILLEQUE, Păul G.

US. Aromic Energy Commisvion

Idatho Operations Office

Post Offke Box 2108

Idaho Folls, Idaho 83401
WALBURG, H. E., Jr.

Oak Ridge National Laboratory

Biology Division

Post Office Box Y

Oak Ridge, Tennessee 37830

WHTMORE, Gordon F.

Untversity of Toronto

Depurtment of Medical Biophysics

Soo Sherbourne Street

Toronto 5, Ontorio, Conada

WLLHOIT, Donald G.

University of Nonth Carolina

Environmental Sciences Dept.

I3I School of Public Health

Chapel Hill, North Carolina 27514

WOLFF, Arthur $\mathrm{H}$.

Environmental Protection Agency

Office of Radiation Programs

5600 Fishers Lane

Rockville, Maryland 20852

IFormerly with DHEW-PHS

Enyironmental Hedith Service/

WOLFF, Sheldon

University of Colifomia Medical Centar

Thind \& Parknassers

San Francisco, Californie 94122

YANDERS, A. F.

University of Missouri

College of Arts and Sciences

210 Jesse Hall

Columbia, Mo. 6520I

YUHAS, John M.

Oak Ridge National Laboratory

Biology Division

Post Office Box $Y$

Ook Ridge, Tennessee 37830 


\section{CONFERENCE PROGRAM}

Session I (Monday morning, December 7, 1970)

Chairman, L. K. BUSTAD

Mammalian Radiobiology

Session 2 (Monday afternoon, December 7, 1970)

Chairman, G.F. WHITMORE

Mammalian Radiobiology (contipued)

Genetics and Cellular Radiobiology

Session 3 (Tuesday morning, December 8, 1970)

Chairman, R. E. ALBERT

Human Epidemiology

Session 4 (Tuesday ofrernoon, December 8, 1970)

Chairmen, W. K. SINCLLAIR

Physics and Models

Exposure Guidelines: The Process

Session 5 (Wednesday morning, December 9, 1970)

Chasman, G. A. SACHER

Meeting as a Committee of the Whole 


\title{
POSITION PAPERS
}

\author{
Mammalian Radiobiology \\ SYSTEMIC AND PHYSICAL FACTORS
}

\section{POSITION STATEMENT ON SYSTEMIC AND PHYSICAL FACTORS}

Pielro Metallı and Grovanm Silın

\author{
CNEN Laboratono de Radiobrologra Anmole
}

The dose corrasponding to a "low level" of irradiation is a relative quantity whose definition requires practicat considerations Radiation protection standards were at all tumes the results of empirical approaches to varıous problems posed by the current qualıtative and quantitative knowledge of radiplolological effects Rather paradoxicaily, therefore, a low level of radiation is that which is thought to induce a low rate of effects, according to our knowledge and experience

The avalable information on the effects of small radiation doses in anmal populations, including man, is extremely limited of all possible effecis, those whinch have actually been found are similar in nature to the long-term lesions observed afier higher exposures Thes frequency is assumed to decrease with decreasing doses down to very small values, praclically undetectable over the background of spontantous eases

Predichons on the ineidence of low level effects in man are founded on the exirapolation to low doses (and low dose-rales) of a few sets of data observed at relatively high doses (and dose-rates) The valudity of the extrapolation procedures is limited by a number of assumptions concerning espectally the shape of the dose effect relatronship [1] Therefore the degree of cunfidence attached to these predictions cannol be properly assessed, but seems largely a matter of apunion, often reflected by the "conservative" position of the international bodres in recomnending dose tumils for human exposure [2]

It would be impossable to base our future action regarding these problems on an attutude which is different from the present pragmatic line The effects which must be considered with the greatest concern for human protecition are those for which a clear cut threshold has not been shown in the dost-effect curves A1 present they apptar to be the imperment of fertilty, seme kunds of developmental lesions, the damage to the genome and the induchion of malugnancres [3]

Estimates of these effecis on human populations may and should be refined, but the level of effect whish is of actual interest for radiation protection should be the guide-hine to furthes experimentation A better definition of these levels for all kinds of damage would be of great help to radıobıological research

It is conceivable, in any case, that further advancements in this field will come primarily from the careful study of exposed humans in all cases where this is praclicable The epidemiologreal studies of such population groups, however, will only provide some key reference points for the human species at relatively hugh doses

All other problems concerung the test of assumptions and extrapolatuons must stul be approached on anumal models, sunce no theoretical speculation will ever solve experimental problems such as the luneanty of dose-response relationships at very low doses The search for such models and a better definution of the experumental practice must presently be pursusd the magnitude of these afforts requires extensive collaboration

\section{References}

1 International Commission on Radiological Protectron, ICRP Publ 8, Evaluation of Risks from Radiatıon Pergamon Press, London, 1966

2 International Commussion on Radiołogical Protectıon, ICRP Publ 9, Radation Proteclion (September 17, 1965) Pergamon Press, London, 1966

3 International Corimussion on Radiological Protection, ICRP Pubi 14, Radisensitivity and Spatial Distribution of Dose Pergamon Press, London, 1966 


\title{
POSTION STATEMENT ON SYSTEMIC AND PHYSICAL FACTORS
}

\author{
J. B. Storer
}

\section{Oak Ridge National Laboratory}

My remarks are made in the contex 1 of a scientific discussion in which we are concerned with the best estimates of radiation offects. They do not necessarily apply to the setting of radiation protection standards where 2 whole series of conservative constrainss must be applied.

Dala from human populations for certain radiation effects (principally cancer induction) are reasonably good in the high dose and high dose rate range. Prospects are good that the data will becone even better as follow-up studies are continued. Even so, there are disagreements as to which cancers can be radiation induced and the incidence to be expected at these high doses. The disagreements are due in part to inadequate estimates of dose to various tissue sites.

There is little or no prospecl of obtaining useful data on human beings exposed to low total doses at low dose rates. To estimate effects at these low doses and low rates it will be necessary to continue to ex trapolate from the effects observed at high doses. The principal value of empirical studies in experimental animals is to provide a basis for these extrapolations.

Are results from experimental animals such as mice relevant? The answer probably depends on the nature of the lesion leading to late sequelae. If the principal irjury is to the information system of the cells, then presumably experimental studies are relevant. One would expect differences in some details of radiation responses, but the general principles should be similar. If the prime injury is not to the information system, then animal studies may be less relevant, but in this case the entire problem is enoumously simplified in that radiation becomes just another toxic agent with the usual threshold for response and sigmoid dose-response curve.

are the following:

Among the genejal principles that have emerged from experimental sludies of somatic effects

1. Protracled exposure is generally less effeclive than a brief exposute to the same total dose.

2. Dose-response curves vary considerably with genotype, sex, and biologieal endpoint. Strict linearity is not often seen.

3. Interaction of radiation with other environmental variables can profoundly affect the shape of the dose-response eurve.

Experimental studies parlicularly needed include further work with variations in dose rale, carefully executed studies in radiation pathology to delermine which diseases can be radiation induced and the nature of the dose-response curve for each disease, and additional effort to understand the basic nature of the radiation-induced injury.

\section{RELEVANCE OF ANOMAL EXPERIMENTATION TO ESTIMATING SOMATIC EFFECTS OF LOW-LEVEL RADIATION IN HUMAN POPULATIONS}

\author{
H. E. Walburg, Jr. \\ Oak Ridge National Labomatory
}

Recognizing that radiation standards for somatic effects have been set by extrapolation of high dose effects in humans, and accepting the probability that low-dose radiation effects in humans will never be directly measured, it is essential to question how animal experiments can be properly utilized to predict such low-dose radiation effects in humbas. It has been popular in the past to hypothesize that radiation induces a generai decrement in cell, tissue and organ function which leads to earlier development of the same lethal diseases seen in unirradiated anirials, the so-called "accelerated aging phenomenon." This general effect, it was thought, leads to the life-shortening effects of radiation, which may be similar in man and experimental animals, whatever the cause of death. There is no evidence to support this hypothesis, however, and the data may better fit another hypothesis, e.g. that life-shortening effects of radiation are due to induction of some speciftc diseases but not others. If this is true then the generat relevance of animal model systems disappears and relevance is found only in motels of the spectic diseases which are observed both in man and the experimental animal under consideration. Unfortunately, many of 
the radiation-induced diseases of the mouse, one of the most common anımal models used in radiobiology, have no human analogs, etther quantstatively or sometimses even qualitatuvely, e $\mathrm{g}$, thymic lymphoma, Harderian gland adtnociacinoma, ovarian tumor Since the bfe-shortening effects of radialıon in the mouse are probably due to such rrelevant doseases, life-shortenjng as an end pount would seem to be equally arrelevant to human radiation biology

In yew of this problem of zelevance, how can anımal experuments prove usefult Certanly where valid models of cadiation-induced human disease exist ( $\mathrm{e}$, chronje granulocytse loukemua) the physical and eproronmental factors important to unduction, such as dose-cate effects, RBE of high-LET radiations, and the influence of host factors can be eveluated Even in the absence of valıd disease models, tmportant information can be gleaned from animal experiments Data from these experiments can lead to "useful generalizations" as suggested by R H Mole Thus if observations on radiation induction of a cerian disease un a wide varsely of species permil a generalization whoch quantitatively fits all the data, it is reasonable to assume such an effect for human populations as well Second, data on the mechanusm of radiation induction of anımal diseases, even though they are not relevant to human disease, may stıll provide the key which will clarify the mechanism by which radiation induces human diseases

\title{
IMPLICATIONS OF DOSE RATE AND DOSE FRACTIONATION
}

\author{
D G Willhoil \\ University of North Caroluna
}

Present State of Knowletge - Dose rate and dose fractionation have previously been recognized as factors which modily the effectiventess of a given radiation dose, but have been cansidered only as potential added safely factors, owirg to a lack of precise quantitative dose-response data Leukemia, life shortering, and genetic mutations in mice have been demonstrated to be dependent on dose cate and dose fractionation Leukemia and life shortening in man have only been demonstrated following relatively high dose rate exposures For example, the exposures of radıologists conssted of numetous small dose fracions delivered at exposure rates in the neighborhood of I R/min Likewse, leukema associated with felal irradiation occurred following exposures of a few roentgens delvered in a brief tume interval Following is a descripition of a model developed in this laboratory recenlly which bears directly on the dose rate phenomesta

Dose Rate Effects - The dependence of cell survival on dose rate can be described by a three. component model The components are 1) sungle-target, sungle-hit, 2) mult-target, single-lut, and 3) repopulation due to division The unuque feature of the model is the introduction of a time-dependent exirapolation number to account for the numer of "hits" which are repared during exposure The model was fitted to experumental HeLs cel1 data, bu1 qualitatively is consistenl with other dose rate studies Conclusions based on the model are 1) increasing dose rates between 3 and $100 \mathrm{R} / \mathrm{mun}$ result in a progresswe uncrease in the rejative importance of the multıtargel inactivalion component, 2) low dose sates $<3 \mathrm{R} / \mathrm{mmn}$ ) gre due to single-target, sungle-hit inactivation, 3) the relative contribution of multitarget, single-hit inactivation to cell killing is greater at high doses than al low doses Sumlar qualitatwe results have been reported for chromosome abnormalities and gerelic effects in mice Russell's tata indicale that the threshold for multitargel mutalions is between 08 and $9 \mathrm{R} / \mathrm{mu}$ for spermatogonia, but for oocytes the dose rate dependence extended down to $0009 \mathrm{R} / \mathrm{min}$ The sungle-target, single-hil component may be attributed to that fraction of the cell population which is in the $G_{2}$ and $M$ phases of the cell cycle which are characterrzed by an extrapolation number of 10 The absence of duvsion in the oocyte may account for the sex Gifference in the dose rate effect

Dose Fractionation. The interpretations of most fractionation studies have been in terms of compansons with single-dose resulis or relative short overall fractionation periods Work in this laboratory has shown that for equal daly exposure rates, the survival times of mice exposed $30 \mathrm{mun} /$ day weye shorier than thase of mice exposed contunuously This difference is readily interpreted in terms of the above dose rate model, that is, low rate irradiation acts primarily by single target interactions and high rate urradiation by both single and multple target interactions

Future Courses of Action. The sole of single and muttiple events in the induction of specific disease entutes should be investigated 


\title{
LATE EFFECTS OF RADIATION
}

\author{
J M Yuhas
}

\section{Oak Rudge Natınat Laboratory}

Radiation standard seting bodres assume that a given dose of radiation will unduce the same uncidence of late effects, whether it is gwen chronically, tn a sertes of fractions, or as a single brief exposure Whule this is contrary to most experimental data, the assumption must be mauntaned since the data presently in hand are unsufticsent for calculating the relateve "sparing" factors for chronic or fractionated delivery

This insufficiency sterns from two facts 1) there is no reason a prort to believe that "sparing factors" will be the same for all late effects and 2) most studies have analyzed single end points aganst single methods of fractionation or chronic admunistration For example, it has been shown that fractionation reduces the Lfe-shortening efficiency of sadiation by a facior of approximately 2 , but that fractionation of appropnate $X$ ray doses increases their ability to induce permanent sterbity in males

As one approach to this problem we are now conductong experıments whoch will analyze a series of late effects (carcınogenesss, life shortenıng. lens opacificaton, sierlization, and immunologic inaparment) following exposure to acute, chrontc, and fractionated gamma rays and fission neutrons In addition, the gamma-ray studies involve a series of total doses (48 $10384 R$ ) received at a variety of dose rates ( $\mathrm{R} /$ day through $\mathrm{R} / \mathrm{second}$ ) $\mathrm{From}$ these latter studies we hope to be able to formulate equations which describe the incidence of late effects as a function of both dose and dose rate By combuning these experiments with studies on the effects of age at exposure on the abuity of singie acute exposures to induce late effects, we should be able to determine the contributions of recovery, age, dose suze per fraction, and lalent peziods requuired for expression to the observed "sparing factors" for chronic and fractionated exposure patterns

We do not propose that the resultant informalion can be used as a direct method of extrapolation to human populatons, but rathet it con estabìsh general princıples withın anumal model systems which can provide a rational guideline for the interpsetation of probable risks in human populations exposed to low total doses at low dose rates

\author{
Mammalian Radiobiology
}

CARCINOGENESIS

\section{CONSIDERATION OF CARCINOGENIC MECHANISMS IN THE PREDICTION OF LOW-LEVEL RADLATION EFFECTS}

\author{
A M Brues \\ Angonne Notwonal Laboratory
}

Radiation carcinogentesis is nol a self-sufficient field $A$ unified theory requires a uzufied concept of carcinogenesis overall, and it is clear that this in turn requires more input from most of the newly developing areas of brology Nor wil one approach suffice we find it useful to examine single molecular events that determine the malignant nature of a cell, but it is likely that any such event or combination of events occurs a great many tumes for every resultung malıgnant tumor Other determining factors that must be looked for le in the interactions between a cell and its envizonment, eithez or both of which may be altered

Several developments in cancer brology have emphasszed factors that were in more or less disrepute, or considered too specialized to be of much general importance To mention a few.

Vuruses . A good deal has been learned about experimental nral carcinogenesss, but thejr relation to the human process is far from understood One human iumor is wetll understood to be assoctated with a virus which now seems to have an antigenc celation with some nonmalignant states it is now known that RNA viruses are capabje of coding the host genome for homologous DNA synthesis, and so far thus seems to be 2 peculartity of tumor vuruses 
Immunologe reactions - Tumors stem clearly to have thetr own unmunologic markers, immunologic tole rance seems to be uncreased by other carcanogens as well as radsation, and tumor-bearing patuents tend to have increased tolerance

Carcunogentic transformatson in vitro. This follows a long process of cultivation following which, after a perod of depressed cell viabulity, changes accur in the intercejlular relations and surface propertes of the newly malignant ce!ls

Plastic carcanogeness . When tissue cells are separated by chemically nonspecific barrers so that they are no longer surrounded by other cells. this leads to delayed tumor development, the same conditions of cell separation (un terms of porosty of the barrer) appear to be critscal un determuning whether differentiation will occur in cultured embryo organs

It wll be seen that in all of the above instances, host factors are involved at least at some point in the process

Among the matters that need to be discussed fully are (1) How do we define a tumor? Does invastveness involve factors outside of the cell' (2) To what extent and on what level (cell and its environment) do aging processes and carcinogeness unteract" (3) Do carcinogenuc agents act addituvely or synergistucally" (4) How can the paradox of ressstance of large anumals to local effects be explanned? ( $\$$ ) What are the actual rules governing varigtions in cancer susceptubutty that are related to tissue growth and the age of host" (6) How much of cancer is actually "spontaneous"?

\title{
THE CARCINOGENIC ACTION OF SMALL DOSES OF DIFFERENT IONIZING RADIATIONS
}

\author{
G W Barendsen, J J Broerse, and C F Hollander \\ Rediobsological institute end \\ Expenmental Gerontology Unit. TNO. \\ Rijswipk, ZH, The Netheriands
}

The induction and development of malıgnant tumours after exposure to ionizing radiations involyes a complex sequence of events, unitiated by the absorption of energy from radtation in biolopical malerial, followed by biophyscal, biochemical and brological changes which finally result in the obserwed neoplasm Because direct expenmentation with very low doses presents great diffıcultres with respect to the number of anjmals required to obtan significant aesults, evaluation of the effectiveness of small doses must be based on adequate knowledge of shapes of dose-effect relations oblained with larger doses and extsapolation, with a suttable theory, 10 low doses and low dose rates Nesther sufficient experimental data nor a generally accepted theory are avalable, however

In principle, dose-effect relations for the production of malıgnant tumours must depend on competition of two factors, namely the induction of changes in cells which can result in malngnant transformation and the induction of cell reproductive death which will prevent part of the potentially transformed cells from contributing to tumour development For the unvestigations of the relative contributions of these faciors, studies of the LET-dependence of the dose-effect relatonships for tumour production by different types of raduations can te of great umportance

Many bological effects of sonzing radıations un mammalian cells, including cell reproductive death and malıgnant transformatıon, are unduced more effectwely by sadıatuons which cause high local energy densitues, $1 \mathrm{e}$, through particles of high LET, than by $X$ tays or $\gamma$ rays For damage to the reproductive capacity of mammal ian cells, dose-effect telations have been measured with 2 varety of radialıons, e $g$, monoenergetic heavy uons and fast neutrons of different energies In view of the competition mentroned, it is clearly of great intecesi to compare dose effect relationshups and the dependence of the relative bıological effectweness (RBE) on the radiation qualtty for umparment of cell prolferation with equivalent data for the carcinogenic action of ionizing radiations

Is order to inwestigate the carcinogenıc effectiveness of lonizing radintions with different distributions of local erergy densty, monoenergetic heavy rons cannot be used because of their limited penetration and changes of LET oxcurring along their path, if organs or whole organisms are irradisted it is necessary therefore to employ radiations, such as fast neutrons or $\pi^{-}$mesons, which produce in tissue secondary particles with a high mean LET

In studies of the carcincegenic actoon of sonzing radiation, lwo types of experuments may be distongushed, aimed at the elucidation of mechanisms operating either at the cellular level or in intact organsms In cases where the total body or a number of tissues in an organisn are irradiafed, the interpretation of results inyolves 
an evaluation of the complex interactions of various types of damage to blood vessels, connective tissues and immunological and hormonal systems For studies of cellular aspects of radiation carcinogenesis, it is preferable to investigate the most simple systems in which tumours can be induced

A few results of sludies of the carcinogenic effectuveness of fast neutrons of different energers in comparison with $\gamma$ rays have already been obtained with rai skin [I] In the system used, a transplantation technique allowed the partial elsminalion of the influence of damage produced by penetrating radiations in subcutaneous tussues Further studies with this system will have to be complemented with invesingations of the effectiveness of neutrons of different energies for tumour production by total body itradiation

\section{Reference}

I G W Barendsen Tumour induction in rat skın by $300 \mathrm{kV}$ Xrays and $15 \cdot \mathrm{MeV}$ neutrons Radiation-Induced Cancer Int Atomic Energy Agency, 1969, pp 413-424

\section{THE RELEVANCE OF MORTALITY AND CARCINOGENESIS AS CRITERIA FOR ASSESSMENT OF LOW-LEVEL RADIATION EFFECTIVENESS}

\section{J Mewissen}

\section{Undressty of Chicago Clines}

Assessment of radiation effects in blological systems is most accurately derived from dose response relatıonshıps Involving a selecled bıological varuate as a function of some radiation parameter(s) We intend 10 revjew briefly each of these components from the critical standpounts of information content and reliability

Although the influence of dose parameters in radiation injury is well known, some of their quantitative implications may be easuly overlooked The absolute magnitude of exposure doses, or in many cases, of absorbed doses, is the usual prece of information at hand, although the spatial distribution on microscopic or submicroscopic scale is actuatly the critical factor (local energy density)

On the other hand, fractionation and/or protraction of dose are manipulated in an attempt to mumic actual human clinical situations For example, daly low-levei exposure of muce is used as a model for chronic (but esgentially discontinuous) exposure of human populations at risk In the resulting complex situation, the concepts of wasted radiation, potential and actual injury [I] are to be kept in mind for proper interpretation of data Accordingly, investigation of single doses may prove more rewarding and be given high priofily

The specific nature of the dose-response function, and particulariy the shape of the curve, is of lesser importance than selection and undersianding of the varıate (bological phenotypic end point) and of the independent variable (radualion dose) It is desirable, whenever possible, to end up with a linear regresson, at least within a given dose range Metametric transformation of coordinates of the graph (probit, logit, log dose) are helpful, but one should realize that they introduce some a prior assumptions on basic mechanisms underlying the brological response In contradistincion with a widespread belsef, lunear versus nonlinear relationship has litte, if any, relevance to the threshold problem A threshold or non-threshold situation can coexist with a unnear, curvilinear of sagmoid curve [2]

As no one knows at what point the "low" dose range star1s, back-extrapolation is unvanably attempted The implicalion is that the function is assumed to be monotonic and continuous beyond the range of experimental data Furthermore, a no-response dose level is by no means an actual threshold level, as the frequency of an itemized response is contıngent on sample suze At the lumit, the enture world populaton would seem to be the only acceptable sample suze for testing a sufficiently infrequent event as a possible radiation response

A fingl word about the most popular variates, I $e$, aging and cancer Is aging a boological inituating process per se or an epiphenomenon resulting from distinct nosological entu1ses ${ }^{7}$ In many instances, aging graphically amounts to a shuft of the lothality function along the tume scale, with no significant alteration of the realm of diseases un control versous uradiated anımals

A sumiar sıtuation seems to preval in radjation "Induced" (?) cancer Recent s1tudies [3] suggest that inbred strains of mice may, with umproved enuronmental living conditions and enhanced survival, exhubit up to 70\% of "spontaneous" tumor incidence It might be that with further extended longevity the $100 \%$ landmark would be approached more closely Such findings gave further support to the theory of verticslly transmitted oncogenes If so, tadiation is no longes an untiatung, but rather a triggerung agent Surtuarly the fit (at least in a major portion) of 
tumor incidence rates to a Gomperizian regression function would seem to indicate that carcinogenesis (spontaneous or Jadiation triggered) is dependent upon two interacting compenent mechanisms, one of phenotypic expression, acting at'a constant rate of force throughout lifespan, and one of repression, gradually losing strength, also at a constant rate throughout lifespan. Obviously a number of biological processess (virus activation, virus incorporation or release, immunological competence) can be pinned on such a phenomenological frame.

\title{
References
}

1. Mewissen, D. J. et al. A formula for chronic radiation dosage versus shortenting of lifespan: Application to a large martunal. Radiat. Res. 6, 450-459 (1957).

2. Mewissen, D. J. La correlation dose-response des radioleucemies experimentale: le probit de marquage. Sang 29, 764-789 (1958).

3. Mewissen, D. J. Dose-response relationship in radiation leukenuia. Nature 183 , 401-402 (1959); Natuse 184. $1669-1670$ (1959).

\author{
Mammalian Radiobiology
}

LARGE ANIMAL STUDIES

\section{THE APPLICATION OF THE LOGISTIC DOSE-RESPONSE SURFACE IN EVALUATION OF TUMOR INCIDENCE FOLLOWING EXPOSURES TO INTERNAL EMITTERS}

\author{
Marvin Goldman, L. S. Rosenblatt, and L. K. Bustad \\ University of Californis, Divis \\ and \\ N. H. Hetherington \\ University of Califomia Ratiation Laboratory. Livermare
}

\begin{abstract}
Estimation of low-level radiation effects in human populations can be facilitated by the use of appropprate animal models. A method is described which permits what we believe to be a reasonable basis for extrapolating the radiation responses in animals at intermediate to high kevels down to exceedingly low levels for which available data may be quite limited. The example chosen is only one of a large number which could be applied.
\end{abstract}

The long-tern bone-setking radionuelide studies at Davis and \$alt Lake City cover a range of exposure doses of up to $10^{3}$ and include over 2,000 beagles at risk for up to 17 years, the maximum lifespan for this breed. Although the Davis study is somewhat younger in time, both laboratories have demonstrated that the major effects attributed to radiation have been the induccion of tumors in tissues within the range of irradistion flux. In addition to the tumors of bone induced by high levels of radium-226 and stronlium-90, the sustained bone marrow tose from ${ }^{\text {}}$ Sr throughout early life adds a risk of inducing fatal myeloproliferalive disorders in beagles at Davis. We have seen no other deleterious radionuclide effects on survival or reproduction at any of the levels tested, correcting the data for radiogenic carcinogenesis.

Analysis of the data utilized all of the animals at risk. In the analysis doșe is related to cumulative incidence rates for each end poin1 (e.g., bone tumor or marrow cancer). The Cutler-Ederer method was used to compute the cumulative survival Jates for dogs on the ${ }^{58} \mathrm{~S}$ and ${ }^{116} \mathrm{Ra}$ regimens. The modification of the life lable method utitized considers mortality to consist only of those individuals manifesting the end point under study (e.g. osteosarcoma). Individuals dying of other causes are treated as "lost to the follow-up" but are considered to be at risk until they die. Individuals alive at the time of the analysis are also cansidered to be at risk for the total time that they are in the study. Computation of the cumulative survisal rate $\left(\mathrm{Ft}_{\mathrm{t}}\right)$ and its standard error $\left(\mathrm{s}_{\mathrm{t}}\right)$ provides the estimate of the cumulative incidence rate, $\left(I+P_{1}\right)$, whose standard error is also $s_{t}$ because of syminetry. An essenial 
and salient feature of this analysis is the fact that all of the individuals are used in the estimation of cumulative incidence rates.

The cumulative incidence rates for osteosarcoma were computed for the pooted ${ }^{236} \mathrm{Ra}$ data from Davis and Salt Lake City. Only the SLC dogs extend beyond 7 years, and represent a very small population at risk. The injected radioactivities for each dosage level differed essentially by factors of 3 . The family of cumulative incidence rates computed tor each of the dose levels were generally "s" shaped and wero not separated by equal intervals on the age seale. In addition, the re]ationship between decreasing dose and maximum cumulative incidence rate was nondinear. The shape of these curves and the ir separation with regard to time suggest to us that the logistic (or growth) curve might provide the most approptiate representation of the data. Furthemore, analysis of cumulative incidence rates using the logistic curve suggested to us that the data could be related to age and $\log$ dose by s logistic response surface from which at least four different estimalions might be attempted.

1. Fitting the logistic equation to individual dose level cumulative incidence rates provides an estimation of the maxiraum eumulative incidence, (M); a measure of the reserves of the individuals subjected to that particular dose level (1/B), which may be analogous to the potential for repair; and the rate constant $(\lambda)$, which decreases the reserves per unit of time.

2. At any given age, provided that data exist, the cumulative incidence rates of the several dose levels are themselwes related by a logistic, and may be extrapolated to estimate cumulative incidence at very low dose levels.

3. The estimated maximum cumulative incidence rates are also related by the logistic, and may be extrapalated to estimate $\boldsymbol{M}$ fot very low dose levels.

4. The ages at which given cumulative incidence (e.g., 1 or Jof $)$ oecurs also follow a logistic and, again, extrapolations may be made to very low dose levels.

The logistic equation may assume many mathematical forms. Its most common form, $E=M / 1+B e \lambda 1$ was utilized here. In graduating the cumulative uncidence cstes, $(E), t$ is taken as age. In graduating the maximurn cumulative incidence jates $(M), t$ is taken as $I n$ dose and $M$ is set equal to 1 . No attempt is made here 10 describe other logistic relationships such as $\mathrm{dE} / \mathrm{dt}=\mathrm{aE}+\mathrm{bE}^{2}$. The significance of the mathernatical corstents in these equations selative to the biological parameters which they, in effect, attempt to estimate is a difficult and complex problemp. Henfy Eyring and Betsy Stover at Salt Lake City have sugested a simila logistic approach utilizing the principles of chemical kinetics to cvaluate radiation dose-effect relationships.

Although the examples cited above were festricted to the effects of bone-seeking radionuclides on the specifie cells at risk with the only end points considered bejng the induction of tumors, this model has wider applicability. We would like to suggest that the model can be utjized for any all-or-none response, provided that the cells at risk remain at risk for the lifespan of the individual. The response surface produced by this model as applied to radiation effects ovaluation utilizos the interrelationship of dose, time, and incidence. For the system under study, a practical threshold is provided by the finite limitation (e.g., Jifespan) associated with the temporal axis. We Jook forward to possible application of this approach to evaluating the dose response of biologic systems other than tumors of bone. In addition, we are currently evaluating variations of this model which consider changes in dose rate and local dose distribution in tissues at risk throughout the individual's Jifespan.

\section{DOSE-RESPONSE RELATHONSHIPS N THE INDUCTION OF BONE SARCOMAS BY RADIONUCLIDES}

$$
\text { C. W. Mays }
$$

\section{University of Utoh}

The incidence of bone sarcomas ws dose has been examined in 11 different studies. None of the Bemúter experiments supports a linear dose-response relationship: at low doses a sigmoid relationship or a "practical threshold" relationship is more probable.

For skeletal irradiation by a emitters, the response is more varied: some a studjes support a linear relationship, whereas others support the sigmoid or "practical threshold" concepts, whert al low doses few, if any, bone sascomas are induced.

In the following table, the observed numbers of cases with bone sarcomas at low dosts are compared with the numbers predicted by (a) the threshold model (natural incidence only) and (b) the linear model in which a radiation-induced incidence (assumed proportional to dose) was added to the natural incidence. 
"P"1 values shown in the last column are the probability that if the linear model were correct, the observed cases (or fewer) could have occurred by chance. The detailed data, to which the linear relationships were fitted, are avalable from C. W. Mays [1-3] .

TABLE I. Observed and Predicted Cases at Lower Dases

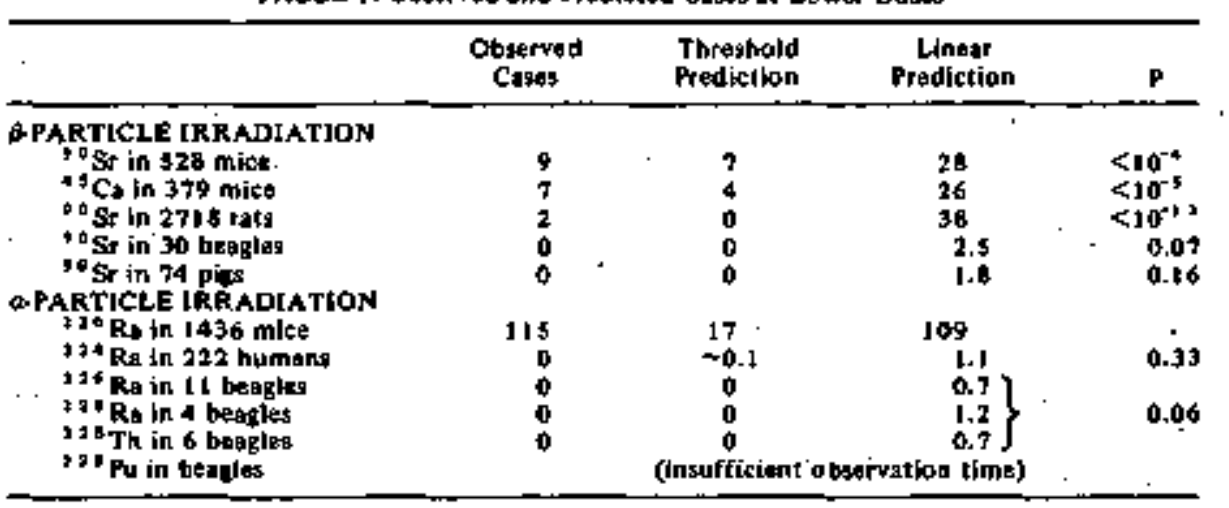

\title{
References
}

1. Mays, C. W. and R. D. Lloyd. Bone sarcoma incidence vs, cadionuctide-dose. The Radiobiology of Phutoniunt. Ed. B. J. Stover and W. S. S. Jee, to be published.

2. Mays, C.W. and R. D. Lloyd. Bone sarcoma risk from ${ }^{90} \mathrm{Sr}$. Biomedical Implications of Radiostrontium Exposture. Ed. L. K. Bustad and M. Goldman, to be published by the U. S. Atomic Energy Commission Division of Technical Information.

3. Mays, C: W. et al. Bone cancer induction by jadionuclides: incidence vs. dose. Hearings on environmental effects of producing electric power. Joint Congressional Conumiltee on Atomic Energy, Vol. Il, part 2. pp. 2192-2210 (Jan. 27.30 and Feb. 24-26, 1970), also in Research in Radiobiology; Uniwersity of Utah Repor1 C00-1 19-242, pp. 385.401 (March 1970).

\section{ANIMAL STUDIES TO ESTIMATE LOW-LEVEL RADIATION EFFECTS IN HUMAN POPULATIONS}

\author{
S. M. Michaelson
}

\section{University of Rochester}

Concem about prolịferation of man-made sources of electromagnetic radiation and "environmental polliution" has provoked reexamination of present Radiation Protection Guides. In sn upsurge of semantical arguments furdamental concepts, scientific facts and philosophic principles are obscured in an attempt to find ready answers in an area which is not black and white but many shades of grey.

What are the scientific facts; how can they or should they be made compatible with political, sochological and economic factors? How does one reconcile the bentfit vs. risk concept with the voluntary risks which society can and is willing to accept for an improved "quality of life"?

The information presently available, although incomplete, dces provide a basis for setting public safety standards for radiation. The present standards are conservative and have nol been shown to result in any injurious ffrects. In the meantime, we must develop concepts and criteria and pursue well-conceived, properly performed, adequatejy controlled studies in animals and man to answer some of the unresolwed problems.

We should diffezentiate between biologic eifect per se, which is non-injurious and quickly and fully recoverable, and injury which is slowly recoverable or irreparable. We should attempt to resolve the questions of threshold, curvilinear or linear Iesponse to low-dose radiation exposure.

In considering the use of "large animal" studies to estimate low-level effects in man, several approaches are suggested.

1. A concerted effort should be made to review in a systematic mannes the accumuiated reported 
and unroported data obtained in past studies on large anivals. By using newer analytic techniques, examining the information in a comparative manner in relation to animals and man according to common physiologic parameters and correlating information pertinent to the low-level effects problem, it is very possible that many of the answers we are now seeking may already be svailable.

2. Planning of additional studies to fill in gaps in the existing information.

tive studies in man.

3. Correlation of data from "large animgl" investigations with relrospective and prospec.

It should be recognized that no single animal species can represent the ideal model and no experimental procedure is universally sujted to all forseeable uses. In selection of the experimental animal, the specific attributes of various species should be evaluated.

Study of several species using a Systems Physiology approach based on various levels of biological organization can provide the most reliable extrapolation factors for man. From a spectrum of species such $2 s$ the mouse or ral, dog, and pig or sheep, basic information on the comparative reaction of biologic systems can be acquired to elucidate mechanisms of action. A common paraneter such as metabolic rate could be utilized to provide an index of extrapolation between species.

\title{
ESTIMATION OF LOW-LEVEL RADIATION EFFECTS OF NHALED PLUTONIUM AND URANIUM MINE AIR CONTAMINANTS IN HUMAN POPULATIONS
}

\author{
J. F. Park \\ Battelle-Northwest Laboratory
}

The present stale of knowledge and confidence in the assessment of the low-kvel effects of inhaled plutonium and uranium mine air contaminants demonstrates contrasting situations. Inhaled plutonium has caused pulmonary neoplasia and lymph node, liver, skeleton, and hematological pathology in experimental aninals al high dose levels, while studies at lower dosts are not completed and biologital effects have not been reported in exposed human populations. Epidemiologic studies have shown an increased incidence of pulmonary neoplasia in uranium miners; however experinental animal studies have thus tar not developed aninal models causing the observed human effect.

Low-level inhalation studies with "soluble" and "insoluble" plutonium in long-lived experimental animals are required to determine the critjcal tissues and dose-effect relationships. Studies in short-lived species will provide needed data, and comparison of the two or more species could aid in developing a much needed more meaningful method of expressing the radiation dose-effect ralationship so results of the animal studies could be more adequately extrapolated to man. The role of the chernical and physical form of the inhaled material on the observed effect must be evaluated in experimental animals. Methods are required to accurately determine the in vivo body burden and distribution of inhaled piutonium in both animals and man. Epidemiologic studies of piutonium workers should include special exposure, clinical and post-mortem evaluation of humans with known body burdens. These known-xposure cases, if properly studied, should provide the most reliable information for estimating low level effects. Consideation should be given to experimental studies in humans using plutoniurn isotopes such as ${ }^{2}{ }^{7} \mathrm{Pu}$ to evaluate inhaled plutonium metabolism in humans.

Since uranium miners afe exposed to a combination of potentially carcinogenic agents, aninial experiments are required to identify the primary etiological agents or combination af agents and evaluate the dose-effect response. An adequate method of expressing the dose-effect relationship must be developed for utilization of the animal data to evaluate human exposures. Human studies should be expanded not only in number of epidemiolowic observations but also emphasizing more accusate dosimetry and exiensive study of the exposed populations.

The lungs of a large segment of the human population are routinely exposed to harmful materials including tobacco smoke and other pollutants; therefore the combined effect of low-level radiation and other agents must be evalualed in human and animal studies to properly estimate the effects of Jow-level radiation on human populations.

When low-level effects are pbserved, calculated or estimated, some consideration must be given to the "significance" of the effect. 
Mammalian Radiobiology

TISSUES AND CELLS IN VIVO

\title{
LATE RADLATION EFFECTS: COMMENTS ON IN VIVO SYSTEMS
}

\author{
E. J. Ainsworth
}

Argonne National Laboratory

One approach to the challenge of the estimation of low-level radiation effects in humants is by interspecies comparisons of life shortening, and of radiation effects in selected physiological systems. Such studies may permit generalizations from a broad phenomendogical base which could bear more directly on estimation of human hazard than would studies with mice or rats alone. It is clear that trarked species differences exist with regard to potential for repair-recovery aftes acute sublethal exposure or during continuous low-lovel exposure. Moreover, phenomena have been encounterad, such as, in sheep, a complete inhibition of recovery during continuous exposure immediately following a sublethal acule exposure, which are not described for laboratory rodents. The extent to which spocies differences based on measurements of short-term end points also apply to lale effects is unclear but deserves attention. Perhaps one of the most important findings from the interspecies studies is the great difticulity encountered in arriving at broad genteralizations. This cautionary facel adds an importan1 perspective to our consideration of extrapolation to man.

One complication of interspecies studies involving Jarge animals concerns the difficulty of in wivo measurements of cell and tissue jnjury. This is but one of many reasons that the laboratory mouse may be used to advantage, since a combined approach involving both epidemiological and physiological description of the populations' responses to low.level irradiation is feasible and rewarding. One in vivo system suitable for estunation of damage to the hematopoietic system involves measurement of changes in the marrow population of colony.forming cells (CFC) together with eslimations of the ablity of transplanted marrow to produce erythrocytes and granulocytes. In this way, insught may be ganned into the compensatory responses, at the tissue and cell level, which are made by irradiated mice. By experimentally inducing proliteration within the hematopoietic system, it may be possible to detect late radiation effects on regulatory systems. Studies of compensatary ot regulatory capability ase of importance, since in the context of low-level radiation effects, stem cell death per st, in some critical systems, is important only to the extent that the stem $\infty$ ll population is not reconstituted. Preluminary sesults show femur CFC content is significantly decreased among aged survivors 700 to 900 days after exposure to neutron or $X$ sadiation. Studies of cell population changes in marrow after fractionated exposure are in progress.

It will be of particular interest to investigate compensatory potential and regulatory systems in mice exposed at low radiation levels when no significant life shortening is detected. Have repais or recuperative process indeed been complete, or will test procedures measuring compensatory responses jeveal injury to homeostatic mecharisms? Were such effects de lected, our views on hazards of low-level exposure might be modifjed, especially when considering the compensalory responses required of human populations exposed to many other environmental hazards. Consideration of the combined effects of low-level irradiation and other environtmental contaminants may therefore be in ordes.

\section{RELATIVE IMPORTANCE AMONG VARIOUS LOW-LEVEL EFFECTS IN MAN}

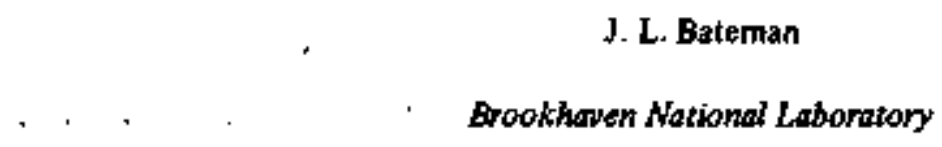

A rigorus investigation of a single low-level cause and effect, as is generally recognized, wll involve ejther or both J) extrapolation downward to the toses of interest from the nearest (higher dose) data in man, and 2) parailel experimental animal studies of the effect of concesn at the doses of interest. The former technique suffers the disadvantage that the extrapolations involved are often long and tenuous, while the latter technigue is handicapped by the difficulty of utilizing samples of sufficient size (for statistical validity) with 
organisms close to man on the phylogenetic scale. With eithes type of approach, a clear detejmination must be made of i) the biological nature of the effect under consideration, 2) the degree of effect, and its causes, in the control population, 3) the degree of effect in the test population, and 4) the physical nature and magnitude of the perturbing intluence. Finally, statistical analytical procedures must be able to deternine accurately the likelihood that the observed effect is not due to chance.

(The studies, to be described, of radiation-induced lens opacification in the mouse fulfil stereral, but not all, of the above criteria.)

A comprehensive approach to the problem, however, should not be confined to the scope embraced by the factors above. In fact, the precision of determination of a given effect caused by a given influence (e.g., induction of myelogenous leukemia by ganna rays) may become relatively less important if either 1 ) the same effect can be more seadily produced by another influence or 2) a different effect produced by a different influence (e.g., induction of.bronchogenic cacinoma by the atmospheric pollutant 3.4-benzpyrene) is of greater clinical significance and incidence.

Prolection of the human population from deleterious influences will be more rapid and effective if the relative importance of these influences (whether physical, chemical or radiant) is determined, and corresponding priority assigned for investigation of the hazard and development of protective measures.

\title{
IN VIVO MAMMALAN RADIOBIOLOGY AND SPECIFIC SYSTEMS
}

\author{
E. B. Darden, Jr
}

\section{Ouk Ridge National Laboratory}

Several statements in the Conference present views on the relewance of animal sludies in general for the estimation of the effects of low levels of ionizing cadiation on the human population. As H. H. Rossi has commented recently, permissible doses have usually been reduced aboul a decade below the level of observable effects. Direct examination of the consequences, if any, of these small amounts of radiation has been nearly impossible, even in animals. My comments are direcled toward the imporlance of sludying in the intact mammal effects of radiation on specific radiosensitive systems or on the induclion of specific lesions. It seems to me that selected in vivo systems can serve one or both of two important purposes: provide a response capable of being exaluated quantistively at $\mathrm{small}$ enough doses to reduce substantially the uncerlainty of extrapolating below detectable levels of effect, and provide a model for the study of mechanisms, hopefully with some general applicability to low-level effects.

We are studying factors affecting dose response and RBE in two relatively sensitive systems in the mouse, (1) the zygote (a joint project with the Federal Aviation Administration) and (2) the lens. In the first. embryo mortality as determined at 16 days' gestation is used as a measure of the effect of radiation given early in the preimplantation stage. A statistically observable effect is obtained at doses below $S$ rads of fission neutrons. Relative survival is approximately exponential with $D_{6}$ of 16 rads or an $L_{s_{0}}$ of 14 rads. The $R B E$ with respect to $X$ rays from 5 to 20 rads is about 4 for single doses delivered within a few minutes. Some of the surviving offspring of irradiated mothers are being kept for observation of any late effects. The practical consequences of the study may be related to the effects of radiation in the human female at an analogous time after conception when pregnancy may not be suspected.

The graded response of the mouse lens to radiation provides a highly reproducible assay (and a nondestructive one) over a wide span of doses with a degree of precision unusual in mammalian radiobiology. In current studies we are examining dose effect in terms of latency and of opacification level for fission neutrons and $X$ rays. The response can be followed over more than a five-hundred-fold neutron dose range down to less than $0.5 \mathrm{rad}$. In addition to supply ing basic information about factors influencing radiation cataractogenesis, the system shows promising results in providing expetimental comparison to theoretical models such as the $\mathrm{J} \cdot 2$ hit theory proposed recently by Rossí. 


\title{
SOME ASPECTS OF ANIMAL AND GELL POPULATION EXPERIMENTS
}

\author{
R. J. M. Fry
}

Argonne National Leboratory

The development of late effects obviously involves complex mechanisns which allow for many interactions of the various regulating systems [1]. In the realm of animal experiments and their role in providing information relevant to human populations, useful generalizations can be sought from data obtained delibejately on a sufficient number of different species. The species differences in sensitivity to late effects, such as tumors and lens opacification, have both defied explanation and been a reason for varied animal studies. The differences in sensitivity between tissues in the same aninal are equaljy obscure. Comparisons, interspectes or interanimal, are made on an organ basis and not relinted to the number of cells in the respective tissue. The use of estimates of numbers cells at risk for neoplastic uransformation for comparisons between organs, within and between species, may be singulariy naive. but perhaps it would focus on the possible reasons for the differences. There is reason to believe that for ejther tumor induction or lens opacification sensitivily is negatively correlated to the number of cells at risk when large and small animals are compared Mole [2], however, has suggested that the whole endosteum of different species is equally radiosensitive for sarcoma induction. The statement is productive, largely because it is prowocative-especially as he points out that one canno1 distinguish between the hypothesis that there are the same number of potential cancer cells in the various species or the hypothesis that the cells, while greater in number in larger animals, are less sensitive. The estimate of the number of cells at risk for a tissue would probably be only of use for comparison, of say, a transformation index of cells in vivo and in vitro, or perhaps the changes with age in number and sensitivity. It is clear that for meaningful comparisons such "local" tactors as repair, the efficiency of removal of abnormal cells, which varies with turnover rate, and postexposure proliferative activity would all have to be determined and incorporated. The comparison of local and whole-body irradiation would be necessary to establish the comparative importance of the interactions. For example, the immunological aspects of suppression of tumor expression may show yariation between species and with ages in unirradiated and irradiated animals. In the lens, лo tumors occur, but the opacities are thought to be the product of aberrant cells. In this system, interactions with the immune system have not got the same importance. Therefore, studjes of the relationships of cell killing. chuomosomal abnormalities and the resultant incidence of opacities on an interspecies basis should provide resulis uninfluenced by cetlular responses elsewhere in the body. Lastiy, comparative studies on somatic mutation appear to be necessary. All that this has said is that much hard-won phenomenological information is needed, and will not be collected in a day.

\section{References}

1. Bruts, A.M. Critique of the linear theory of carcinopenesis. Science $128,693.699$ (1958).

2. Mole, R. H. Endosteal sensitivity to tumor induction by radiation in different species: A partial answer to an unsolved question. Deloyed Effects of Bone-Seeking Radionuclides. Ed. C. W. Mays, W.S. S. Jee. R. D. Lloyd, B. J. Stower, J. H. Dougherty, and G. N. Taylor. University of Utah Press, Salt Lake City, 1969. pp. 249-26].

\author{
Cenetics and Cellulat Radiobiology
}

GENETICS

\section{GENETIC EFFECTS OF LOW-LEVEL RADLTION IN HUAAN POPULATIONS. STUDIES WITH DROSOPHILA MELANOGASTER}

\author{
Seymour Abrabamson
}

University of wisconsin

The ptinciple of linearity of radiation dost-mutation relationships has been the view long put forth by geneticists in estimating penetic risk from low doses of irradiation. This is a conservative view only if mutation 
rate is proportional to dose or if there were to be a threshold found at very low doses On the other hand, if there were an exiremely sensstuve and substantally suzed populatson of umportant gesm cells (e g, gonjal) which were both highily mutable and kiled by low doses or irradiation, then in fact the concept of linearity might underestunate the hazard's of low doses when extrapolations from untermednate or hugh doses are carried out For this reason it becontes umportant to obtan critucal low-dose anformatzon on the unduction of mulations in tritucal stages of germ cells in Drosophula and mammals Work in our laboratory at present undicates that oogonial cells do not possess a detectably sensitive population of eells that would lead to a departure upwards from the expected linearty at low doses In fact, a test of over $77,000 \mathrm{X}$-chromosomes fals to show a significant uncrease in the induction of sex-linked lethal mutations for doses of 20,100 , and $500 \mathrm{R}$ as compared to the control On the other hand, the work of Oftedal does sugest that Drosophula spermatogonia possess a sensitive fraction of germ cells $I$ am uncertain at present whether this population would contribute a substanial mutation component that would significantly alter the estumated mutation rates for human populations at low doses ( $1 \mathrm{e}, 170$ mollirads per year) if an equivalently sensitsve population existed for human cells

Other studies in our laboratory on the induction of translocations in mature oocytes at doses of 0 , $10,50,150,250$, and $500 \mathrm{R}$ demonstrate the following umportant points

I Ten roentgens signifieantly increases (by more than doubling) the rearrangement frequency

2 Rearrangements are induced in a linear manner up to a dose of $50 \mathrm{R}$ and in a quadratic fashion above $50 \mathrm{R}$ This extends and corroborates the work un mature sperm of Drosophuta, bone marrow cells of man, and spermatogonia of the mouse

3 Lunearity al low doses suggests that factors such as dose rate and dose fractionation will be unimportant in the mutation or rearrangement process, since the induction event zesults from a single conizatoon track

\title{
A PROPOSAL TO ESTARLISH VITAL STATISTICAL MONITORING SAMPLES IN SELECTED GEO-ECONOMIC REGKNS OF THE CONTINENTAL UNITED STATES TO DETECT POTENTIAL DETRIMENTAL EFFECTS OF LOW-LEVEL ENVIRONMENTAL HAZARDS
}

\author{
Douglas Grahn
}

\section{Argonine Nattonal Laboratory}

In recent years, slandard wital statıstıcal data have been exploited to demonstrate alleged radiation effects (at fractions of natura] background levels) in terms of increases or time-trend changes in fetal and infant mortalsty zates, and adult mortality patterns Under most circumsiances, gross unadjusted mortality rates are relatively insenstive to munor perturbations in the normal array of environmental, cultural, and biological factors that influence mortality Although sorne causes of death may be responsive, most analyses put forward today are grossly deficient in their simple recognition of the impact of many common socroeconome and raciat yariables on mortaljty Because vital statistical data are cheap and plentuful, though nol without some troublesome inaccuracies, the question becomes, what can be done to make such statistucs a more valuable and sensituve continuous monitorung system of the biologieal effects of envionmental agenis?

To start, all factors known to unfluence mortality need to be clearly defined, so the uninituated will give more thought to the interprelation of variations The intrinsic variance, or random component, needs to be quantitated The relative sensitivity of different end points to changes in the miagor independent varables also requires some elaboration All of this, however, merely precedes whal should be done-1he establishment of selected representative master samples or sampling regons that ean be used for longitudinat study of the vital statıstical parameters that may be significant indicators of unjury produced by persistent low levets of environmental stress

The selected samples should represent the major geoeconomuc regions of the continental United States, for example, New England, the industral Midatlantic, the racially and economically heterogeneous Southeast, the cash-grain ccop Midwestern region, and olhers Regional patterns of mortality and signuficant socioeconomic variables should be identufed A general envronmental montoring program should be set up to evaluste changes al least $m$ the following wates supply, air-borne contamunants, therapeutic drug usage, occupational patierns, migration, racial components, income, education, and medical support prograns Age and cause-specific morlalıly un unfants and adults can then be baseluned for longitudunal, unler-regional, or other comparisons As no true "control" population is avalable, each sample regen becomes is own control in tume If a 
question should arise about the possible detrimenial effect of a nucleat power station, for example, the necessary data will be instantly available.

More sophisticated monitoring systems have also been recommended recently by Neel $[1,2] . A$ sel of regional master samples, as recommended here, could provide the material to fulfill Neel's suggested requirements for the detection of eytogenetic and biochemical genetic changes. Neel considers that only a few selected vital statistical events can be dependably monitored for changes in mulational pressure. This may be the case, but present-day environmental problems have both somalic and genetic damage potential. As recently noted by the Assistant Surgeon General of the U. S., exposed individuals are seriously threatened by the synergistic action of two of more factors, and cause-specific death rates may, therefore, detect somatic injury very efficiently. The fact that crude measures of iniant mortality are now being used to measure alleged radiation effects makes it imperative to establish the basic mortality patterns and control factors, as it is certain these statistics will continue to be used both wisely and unwisely. Lastly, it would be ideal 10 coordinate gentic and somatic measures of injury in the population, if any sensible estimate of the biological effects of long-term multigeneration, low-level environmental stress is to be made.

\title{
References
}

I. Neel, J.V. Evaluation of some genttic consequences of a deteriorating enyironment. Testimony before Subcommitte on Intergovernmental Relations, U. S. Congress, Aprid 24, 1969.

2. Neel, J. V. Lessons from a "primitive" people. Science $170,815-822$ (1970).

\author{
Genetics and Cellular Radiobiology
}

\section{CYTOGENETICS}

\section{CYTOGENETICS}

\author{
A. B. Reiskin
}

The University of Connecticut

A review of the cytogenetic literalure indicales that most radiobiological phenomena apply to structural changes in chromosomes as well as to intacl cells. The degree of damage or number of aberrations varies as a function of the total dose, radiation quality, time and method of sampling, conditions at the time of exposure, dose rate (depending on quality), cell age and other factors. The oxygen effect and/or protection by inert gases may be an inportant exception.

Cytogenetic end points, however, often only reflect the injtiation of some metabolic, oncogenic, genetic, or other process and in themselves may be of little direct consequence. Dulbecco has pointed out that radiation-induced breaks in DNA may be the insertion sites for tumor viruses, and thefe seents to be developing evidence that viral antigens sometimes appear in tissues after irradiation. It is already cleat that radiation enhances transformation by viruses, but the mechanics are poorly understood. II has also been recently demonstrated thal stable cell lines with chromosome-specific biochemical lesions can develop as a consequence of irradialion. Again, the qualitative and quantitative relationships between radiation.inducted chromosome changes and these phenomena are unclear. The problem is further compounded by the fact that in the areas of greatest concern, namely, low dose partial body exposure, the required samples are large and difficult to obtain.

The nature of the problem indicates a need for two lines of attack. Assurning a model in which radiation-induced chromosome changes lead to cell death, or to alterations in normal function, the furst step is satisfying a requirement for a precise definition of the lime, dose, and quality functions of aberration production. Precision, particularly in the case of small, low-frequency events, is beyond the scope of manual evaluation and will require automated analytical techniques. The aulomation of karyotype analysis is advancing capidly, bul it will be necessary to define the parameters relevant to radiation effects since they may differ from those required for other purposes. Second, assumptions linking struclural changes in chromosomes to tumor induction, metabolic disense or other sequelae can and should be experimentally tested. 


\title{
STATEMENT ON CYTOGENETIC EFFECTS OF LOW-LEVEL RADLATION
}

\author{
Sheldon Wolff \\ University of Colifomia Medical Center
}

Over the years, many effects of radiation have been studied rather extensively, but among the most extensively studied has been the induction of chromosome aberrations. It is genezally believed that when cells are killed by low doses of radiation, the sensitive target is the cell nucleus, i.e., that it is damage to the genetic material of the cell that results in cell death.

Arguments have been constructed showing that, of the various types of nuclear darage, only chromosome aberrations can quantitatively account for the changes in cell survival. There are other arguments indicating that atmost all mutational events, be they true point mutations or chromosome aberrations, are detrimental or deleterious. Consequently, almost al geneticists agree that radiation-induced mutations are harmful, and that any increasted amount of radiation which will increase the number of mutations, will also be harmful. In spite of this, and in spite of the fact that over the yeas very much work has been performed in this aren, we still bave the problem that we do not know exactly how much genetic damage will be caused by very low doses of radiation, nor can we tell exactly how harmful this darnge will be.

The reasons for this are manifold. For instance, dicentrics comprise one of the major types of chromosome aberrations studied cytologically. In human celis, these aberrations have to be observed in metaphase preparations that have 46 chromosomes. The chromosomes have to be counted and studied individually in order to pick out such dicentrics, and consequently the preparations have to be of very high quality. Al this time, this has become somewhat easier, but in the past it was rather diffieult. Earlier, people looked at only some SO human cells per point. It was much easier to deal with plant cells that had much larger chromosomes, and then to make extrapolations to the human case. Now that mammalian cylology has improved, this is no longer as serious a problem as it was, hut at low levels of radiations, where the aberation yields are low, it is still very arduous to obtain statistically stignificant tesults.

This can be readily seen when one considers the shape of the dose curves for the induction of dicentric chromsome aberrations that require iwo breaks. With sparsely ionizing radiations, these aberrations increase approximately as the squist of the dose. Therefore, at very low doses, there are very few aberrations. Thus, even with good preparations, it is very difficuli to obtain enough of these aberrations after low doses to determine 'the difference from controls with any statistical precision. To fix our ideas on this, we can note that with a dose of 5 rads we might expect only 0.00032 dicentrics per cell, which is very difficult to distinguish from the spontaneous yitld.

At least three different studies carried out on aberrations in radiation workers have suffered from such difficulty. Although, in general, such studies can show how low level doses of radiation are able to induce aberrations in humans, it takes very large numbers of oells to determine whether the level is higher than in the controls. Futthermore, there is a great deal of varialtility from person to person irradiated.

All of this is further complicated by the fact that dicentric abertations, which are anong the most common, are subject to an intensity effect, with tewer dicentrics being formed at low intensities of irradiation than after acute doses. Since most low-level experiments are carried out at low intensities, this tends to reduce the number of dicentrics even more, and thus make it even more difficult to obtain statistical differences. In addition, it is difficult to obtain a control value because the individuals who comprise the control population frequently have been exposed to dental $X$ rays, medical $X$ tays, caffeine, chemical and environmental pollutants, or viruses that can break chromosories.

But even if we did know exactly what the yield of chromosome aberrations was, especially after low doses and low dose rates, geneticists still couldn't tell you how bad this is The reason is that most chromosomal aberrations of the type that are scorable in cytogenetic preparations are not passed on ta succeeding generations. As a matter of fact, they are not ever passed through very many cell divisions in somatic cells. These aberrations have been called unstable aberrations and are actively selected against. That is, they lead to cell death either because a fragnent with a lage number of genes is not inctuded in the daughter cells or because the abertations form bridges that prevent cell division.

Consequently, it is seen that the problem is twofold. First, it is extremely difficult to obtain the data necessary to establish statistically significant differences between control populations and those exposed to low levels of Iadiation; and secondly, it is difficult to make a precise estimate of the degree of damage associated with 
such aberrations that are actively selected against and replaced with normal celts. The developmental changes that occur because of such selection are largely, if not completely, unknown.

\title{
Genetics and Cellular Radiobiology
}

\section{CELLULAR RADIATION BIOLOGY}

\section{CELL CULTURE STUDIES RELATIVE TO MUTATION AND TRANSFORMATION}

\author{
M. M. Elkind
}

\author{
Brookhaven National Laboratory
}

\begin{abstract}
Assessment of present state of knowledge
Msmmalian cells grown in culture are currently being used co study mutation production. Cell transformation is also being studied in the contexts of cell-to-cell controls of proliferation, the role of chemicals and viruses, and the use of the transformation end point in connection with mechanisms of carcinogenesis. In reference to transformation studies, some results have been published demonstrating an enhanced effect of jonizing radiation [1-3] although this is not always observed [4].

Concerning cell transformation, a comprehensive picture is not available as yet, nor is the role of radiation clear. Futher, studios of repair of radiation induced cell transformation (or mutation production for that matter) are few and as yet not very enlightenung. As might be expected with the limited data available, even less is knawn aboul whether or not drugs and/or viruses can act synergistically with radiation. Finally, little is known about a possible dependence of mutation and carcinogenesis on radiation quality.
\end{abstract}

\section{Eualuation of future courses of action}

Three kinds of related depatures are worth pursuing with mammalian cells in vitro.

First, there is aeed fot the development snd/or improvement of end points with which to assay mutation and carcinogenesis more rapidly than can be done in animal systems.

Second, with current and/or improved end points, dose dependencies need measurement, and the roke of radiation quality needs assessment.

Third, as one important approach for the study of mechanisms, for the guidance of animal studies and for the estimation of incidences at low dose and low dose rate, a search for repair processes and their relation to repair relative to other end points should be pursued. This should be done as a function of LET to help develop a comprethensive understanding of the forward and back reactions. This third departure relates to the "threshold question." Its relevanco to this conference is ovident.

\section{References}

1. Stokes, M. Nature 200, 756 (1963)

2. Borek, C. and L. Sachs. Proc. Nat, Acad. Sci. 57, 1522(1967).

3. Pollock, E. and G. Todaro. Nature 219,520 (1968).

4. Klein, J. C. J. Nat. Cancer lnst. 37, 655 (1966)

\section{CELLULAR RADIOBIOLOGY AND LOW-LEVEL RADLATION EFFECTS ON HUMANS}

\author{
W. K. Sinclair \\ Argonne Notional Laboratory
}

Studies on single mammalian tolls in vitro $[1,2]$ have been very sluccessfol in quantitating Jadjation responses such as lethality, division delay, and vasious biochemical changes. Most of the data partaining to 
the shape and parameters of mammaltan cell survival curwes, and the manner in whuch they are modufied by radiation features (dose rate, LET, fractionation, etc), physiologicsl parameters (oxygen, temperature, postıon un cell cycle), of Inhibitors, sensituzers, protective agents, etc have heen oblanned by studies in cellular systems in vitro [3] Cosresponding, but usualiy less precise, expesuments un vivo have rendered in vitro data useful and applicable, within Jımits, to some in viwo cell compartments (much more 18 , however, needed here) Cellular models may then be developed [4] which, in cettain instances, can predict or explan responses in whole antmal systems For example, experiments on the effects of $\mathrm{X}$ rays and fast neutrons from the JANUS reactor on mammalıan cells in vitro undicate that $2 t$ is likely that recovery oxcurs in mice exposed to fast neutrons, but to a considerably lesser degree than after $\mathrm{X}$ or gamma rays

With respect to low-level radiation effects in humans, two aspects of cellular studies 1 n vitro are of particular sıgnificance

First, the effect of low doses of radjatron has been quantitated un some cellular systems, and these data may have some predicive value for whole organisms The multitarget, single hit model commonly employed to fil mammalsan cell survival curves [5] predicts that at very low doses ( $1 \mathrm{e}$, at the origin) the survwal curve should have zero slope Expenmental studies indicate that this is probably not the case Several workers have found in asynchronous oells that survival data are belter fitted by a two-part model in which a low initial slope (with $n=t$ ) is followed by a later steeper slope [5-8] Differences in $D_{0}$ amount to a factor of 2 or 3 To avoud the complicalions of mixed responses in asynchronous populations, Morton and I examined synchronized Chinese hamster cells in late $S$ in the region above So\% survival [9] We found that the slope near the origin was not zero, but corresponded to a $\mathrm{D}_{0} \sim 550$ rads initially, compared to a funal slope with $\mathrm{D}_{0} \sim 190-200$ rads

Thus, (1) even at the lowest dose some effect was observed, and presumably this contunues to very low doses, and (2) ignoring other interpretations of the model, the response of these cells has two parts, a small but positive intul dependence on dose, followed at higher doses by a greater dose dependence The response is evdently not uniform over the whote dose ronge

Extension of these experiments into the very low dose region requres, for statistical reasons, a "megaplate" experıment Nevertheless, some further extension would be desirabite

Second, the response of most current concejn at low doses is the incidence of tumors Little is known about the cellular basss of carcinogenesis For example, the transformation of a normal cell into a malignant one by radiation must be a sublethal event, but what thus event involves has been litlle investigated This is partly because the identufication of malsgnant changes in cultured cells still requires further development, including confirmation of the capacity of transformed cells to induce tumors in antmals The method has so far been more useful for the study of chemical carcinogens than for radiation [10] However, development of this end point in culture would be an umportant step in the furthes investigation of cellular carcinogenesis and of low level radiation effects

Thus, $\mathrm{t}$ identily the important problems fot the future in the cellular area as (1) further development of methods of Iranslating data from in vitro experiments 10 in vivo situations, (2) further low dose and low dose rate unvestigations in culture, (3) the tevelopmenl of approprnate assay methods for iransformed cells in culture, and (4) the investigation of the cellular basus of radiation carcinogenesis using these assay methods

\section{References}

I Puck, T T and P I Marcus Proc Nat Acad Sci 41, 432 (J955)

2 Elkınd, M M and G F Whutmore Radrobrology of Cultured Mammatian Celis Gordon and Breech, New York, 1967

3 Sinclar, W K X ray survival of mammalan cells in culture Comparative Cellutar and Spectes Radiosensifurity

Proc Symp, Ed V P Bond and T Sugahara Igaku Shom, Tokyo, 1969, Pp 65.78

4 Elkınd, M M Fundamental Aspects of Radrosensttvily Brookhaven Symposia in Biology /4, 220-245 (1961)

5 Sunciar, W K The shape of survival eurves of mammatian cells in vitro laEA Technical Report, No 58, int Atomse Energy Agency, Vienna, 1966, p 21

6 Bendes, $M$ A and $P$ C Gooch lnt J Rad Biot $S, 133$ (1962)

7 Barendsen, $G$ W and $H$ M D Walter Radrat Res 21,314 (1964)

8 Hall, E I NCI-AEC Conference, Brookhaven Natıonal Laboratory Report BNL.50203 (1970)

9 Sanclar, W K and R A Morton Radiat Res 29,450 (1966)

10 Keın, 1 C Radiation Induced Cancer Int Atomic Energy Agency, Vienna, 1969 


\title{
IN VTTRO STUDIES OF GENETIC AND CARCINOGENIC EFFECTS OF RADLATION
}

\author{
G. F. Whitno's
}

\section{Ontorio Cancer Institute}

The growing awareness of the potential genetic and carcinogenic hazards arising from radiation and a host of other environmental pollulants requires the development of methods for sereening for the effects of such agents. While in some instances it may be necessary to carcy out such studies in small mammals, considerations of cost and converience suggest the ise of mammalian cells in vitro. Partly as a result of the growing awareness of this need, and partly for various other reasons, a number of groups have begun the sludy of various aspects of mammalian cell genetics in vitro. To date most of these studies have been concerned with isolating and describing the properties of both drug-resistant and suxotrophic mutants, and techniques have been described for the isolation of mulants of both classes. In addjtion, there have been several seports of attempts to use these systems in initial attempts to determine the mutagenic efficiency of both ultraviolet and ionizing radiation, and also of a group of known mutagenic agents. From the studies alresdy reported it is obvious that the system suffers from a numbet of difficulties. With most cell lines in cultura thete is still considerable question as to the genetic composition, including frequency of monosomic regions, etc. Also, there is considerable uncertainty concerning ovesall genetic stability during growlh in vitro. In addition to these uncertajnties, there are technical problems in that the mutation frequency observed depends upon factors such os the initial cell population size in the test dish, the time allowed between mutagenesis and expression, and the kevel of the selecting drog used in the selection procedure. It is doubtful, however, if even this array of potential difficulties can explain the apparent discrepancies between the values reparted for the mutagenic efficiencies of $\mathrm{X}$ rays in two mammadian test systems, one Josking at drug resistance and the other at the induction of a glycine defichency. Obviously a great deal of work remains to be done on the development of the sysiem. Nevertheless the beginnings of a useful system appear to be at hand.

In addition to the spectre of radiation-induced mutations introduced into large populations exposed to low levels of radiation, there is also the spectre of radiation-induced malignancy. Here again, there are possibilities that cestain aspocts of this can be investigated with in vilro systems. The development of in vitro assays for viral transformation open up the possibility of using the same assay systems for studying radiation-induced transformation. In this connection, one aspect which would appear to deserve a great deal more attention is the possible interaction betweten viruses and radiation in the production of malignancy. Most DNA tumor viruses would appeas to require incorporation into the cell's genetic apparatus before they can bring abrout tfansformation. Evidence is accumulating that this incorporation can be fostered by the presence of nicks in the DNA introduced by chemical agents, including a variety of known carcinogens. Since it is known that radiation can also produce such nicks, there would appear to be a possibility of a synergistic effect here also, an effect that might also be investigated in vitro.

Hased on the above reasoning, there would seem to be a greal deal of merit at the present time ir the further development of in vitro systerns for testing both for mutagenic and for ancogenic effects of low levels of radiation.

\section{Human Epidemiology \\ FOLLOW-UP OF EXPOSED POPULATIONS}

\section{HUMAN EPIDEMIOLLOGY}

\author{
R. E. Albert
}

\section{New York University Medical Center}

There is a strong suggestion of an approximately linear nonthreshold dose-effect relationship for leukemia in Japanese atom bomb survivors as well as X.irradiated spondylitics. Although the "threshold" form of dose-effect curve is observed in most experinental studies relating carcinogen dose to tumor incidence, any doubt 
that there is such a thing as a lunear nonthieshold tumor response is dispelfed by the data relating lung cancer an humans to the daly consumption of cugareties The practical implications of a nonthresheld dose-response relationship are repellent because it inevitably produces the dilemma of attempting to equate the cost in human life agsinst the amenitits of life produced by technology

Although it may be wishful thinking, these so one consuderation that might lead to a practucal amelioration of the problem, namely, if the apparenl nonthreshold dose-response relalionship were really the compostte response of a series of subpopulations of graded susceptibisity If so, the identufication and special proiection of such hugh risk populations might sigmfucintly reduce the cost in lives associated with any given level of carcinogen exposure That such high-risk subgroups exist is clearly ullustrated by the wellknown genetically determined dssease, xeroderma pigmentosa, whuch unvolves a defective mechanısm for repatr of DNA unjury csused by ultraviolet radiation, together with a remarkably high susceptsbility to skin cancer induced by sunlught

These considerations lead to the ussue of how the degree of susceptibility to a partscular carcinogen for a given form of eancer relates to the spontaneous incidence of that cances One gains the umpression from expermental dats that a nonthreshold lype of lumor tesponse to a careinogen occurs where there is a rejatively high spontaneous incidence of the partscular cancer under study If an approximately constant radiation dose were required to double the spontaneous unidence of any type of cancer, it is clear that the spontaneous uncidence of a cancer would have a strong effect on the shape of the response curve and the existence of an appartent dose threshold

\title{
THE EFFECTS OF RADIATION ON THE FETUS
}

\author{
M L Griem \\ Universtity of Chtago Climits
}

In 1968 in the Journal of Reproductive Medicine I took the following positton in the summary of a review article on the effects of radiation on the tetus

1 High doses of tonizing radiation above 50 rads will result in gross congenttal malformalions These malformations will vary with the stage of gestation at which exposure to $\mathrm{X}$ ray occurs

2 The developing central nerwous system is very sensitive to oomzing radjation, and doses above 15 rads will result in frank abnormalities

3 Exposures of 15 to 3 rads may result in an inereased frequency of tumors, ether bethign of malıgnant

4 Below doses of 1 rad there seems to be little evidence that the fetus is injured

5 Radioactive isotopes admunistered to the mother can cross the placental barret and result in Injury to the feecus

6 Dizgnostic $X$ ray exposures of the maternal pelvis should be avoided, especrally during the first tumester of pregnancy

7 Diagnostic chest $X$ fays and $X$ rays of the skull and extremitres have not been mplicated in radiation injury to the fetus

This position can be modified two years later by additional data supplied by $\mathrm{L}$ Jacobsen who has evaluated the somatuc effects of radiation on the felus and has extended the observations of the Russels in a monograph entıled "Low-Dose X-Radıation and Teralogenesis" The other area which has changed somewhat in the past two years is that of carcinogenesis Thre inleresting papers have been presenled One is by Robert W Gibson and co-workers pointing out the increase in leukemia in chidren exposed to multiple risk factors, one of which includes in utero radiation of the chuld Alice Stewart has added some additonal information to the concept that radiation may undue cances On the othes hand, recent work by Jablon and Kato analyzing almost 1300 children exposed prenatally to the atomic bombs has not demonstrated an excess mottality from leukemia and other cancers These most recent data in the prospectuve siudy of Jablon sase some questions concerning the previous retrospecive studies by Gibson, Stewart, and MacMahon

The positıon one maght lake now whth relation to fttal uraduatwon and carcunogeness is that the rusk is less and that the frequency of tumors induced by prenatal raduatıon is less than previously expected Brent has added additional data concernung the lack of effects on the central nervous system as measured by changes in nervous function A number of others have contributed to the growing body of data about whych isotopes cross the placental baries and enter the fetus. This work has been reysewed by Sukov 


\title{
LOW-LEVEL RADLTION EFFECTS IN HUMAN POPULATIONS
}

\author{
L. H. Hempelmann
}

\author{
Strong Memorial Hospitul
}

\begin{abstract}
Assessment of present state of knowiedge and confidence
Almost all of the predictions of the effects of low level exposure to ionizing radiation in man are based on extrapolation of data from human populations exposed to relatively high doses (usually over $100 \mathrm{R}$ ) deliwered at a bigh dose rate (over SOR/minute or more), often to a limited portion of the brody. The only populations at present available for direct study of low dose effects are (1) human fetuses exposed to a few rads of $X$ rays at high dose rates, (2) hyperthyroid patien1s treated with ${ }^{13} 1$ with a resultant total-body dosage of several tens of rads at a relatively slow dose rate (plus a large thyroid dose), (3) a few hundred Marshall Islanders exposed to sather uncertain doses of external and internal radiation at a relstively high dose rale from radioactive fallout, and (4) a lange population of Japanese at some distance from the hypocentes of the nuclear explosions, wilh resultanl exposure to small doses of uncertain magnilude delivered at a high dose rate.

Since the results of al] of these studies are at best uncertain in one aspect or another, we musl use the available data on persons exposed to relatively high doses at high dose rates to assers the risks of low level exposures. In keeping with the usual policy of maximizing estimated risks, we make the most conservative assumptions in extrapolating the values to low dose levels, namely, we assume that the linear dose response observed at the high dose levels and high dose rates also holds at low levels of doses and dose rate. In other words, we assume that no recovery occurs at low doses and dose rates, a pessimistic assumption in view of the demonstrable recovery of cellular damage in animal and tissue culture experiments. As far as the confidence in the extrapolated risk values is concented, we are certain that these estimates are at the upper limit of the possible effects if one extrapolates from the rapidly ascending part of a valid linear doseeffect curve. We have no idea how much less than the maximum the actual risks may be. The confidence limils, then, are between the upper estinated risk and zero.
\end{abstract}

\section{Evaluation of future course of action}

[n my opinion, the following course should be pursued to solidify the data on risks of low-leve] radiation exposure.

1. Intensify mathematical treatment of dose-effect relations extrapolated to low doses.

2. Set up intensive experimental studies of the shape of the dose-response curve at low doses and dose rates, and of the mechanisms of cancer induction under these conditions.

3. Continue animal experiments comparing effects of the same doses of ${ }^{1}{ }^{\prime}$ ' $I$ and $X$ rays, such as have been done for cell killing and oncogenesis in rat thy roid.

4. Continue and exiend exisling epidemiological studies.

5. Look for new study populations, preferably irradiated at low levels, e.g., technical and supportive staff exposed to fallout at the 1951 Eniwetok lests, children given tracer doses ${ }^{13} 1 \mathrm{I}$, e1c.

6. Set up a panel to evaluate objectively the comparative risks of nuclear vs. other power sources. This should be composed of distinugished scientists who have nol previously been associated with the radiation field, but who think in terms of probabilities and who can analyze dala objectively.

\section{SOME RECOMMENDATIONS FOR EPIDEMIOLOGICAL STUDIES}

\section{E. L. Saenger}

\section{University of Cincinnati College of Medicine}

The probability of isolating additional unique low-level effects attributable to radialion by experimental methods seems low. Historically, the only data which contribute to our understanding of somatic effects, insofar as radiation slandards are concerned, are human dats; and of these by far the most useful data are obtained from epidemiological investigations. 
My personal view continues to be that the present radiation standards are entirely adequate $[1,2]$ and that no changes should be made until new information becomes available which indicales clearly the need for further modification. Based on existing data one can show the reasonable possibility that certain present standards are too rigid just as well as one can consider that the same standards are too high. These statenents do not indicate an opposition to the search for effects associated with low-level radiation: well planned studies are highly desirable, particularly in view of current public apptehension.

A principal source of confusion of some recent studies lies in the practice of comparing populations with grossly dissimilar characteristics, usually a diseased group vs. the population at large. In Beneral, retrospective studies have been of only suggestive he]p in identifying association [3]. Usually thoir appeal is an economic one. It will be necessacy to identify prospectively populations receiving low doses (0.1 to 20 rem) and arrange long-term followup both of the irradiaied and comparison cohorts.

Specific study areas include furthes investigation of alterations of sex ratio, abrormalities of development following diagnostic $X$ irradiation early in pregnancy, and abnomblities in children receiving "high" doses to the genitourinary tract. Further correlation between cytogenetic changes in irradiated children and subsequent manifestations of such abnormalities should be considered. Most investigations of these kinds will require collaboration between many large centers.

The earlier record-keeping proposals of $\mathrm{AEC}$ should be re-examined. It should be possible to follow individuals who receive $l$ to $5 \mathrm{rem} / \mathrm{Yr}$, if they are properly identified. Agein, it will be necessary to identify appropriate comparison groups. Adequate follow-up must be assured. Access to Social Security records should be simplified greatly, so as to make appropriate follow-up more precise and less costly.

The concept of benefit vs. risk is so loosely used that this matter needs thorough re-evaluation so that a language of benefits can be developed. Consultation with elinical epidemiologists and actuaries will be helpful in this regard.

Finally the relatively high costs of these programs should be considered. They will probably be less costly than the expense of making standards more rigid in the absence of seientific evidence. It is essential that we be right for the right reasons.

\title{
References
}

1. Saenger, E. L. Radiologists, medical radiation, and the pubtic health. Radiology 92(4), 68 1-699 (March 1969).

2. Saenger, E. L. and W. Stumpe. The future of radioisotopes in medicine: Benefit vs. risk. Medical Radionuclides: Radiation Dose and Effects, Proc. Symp. held at the Oak Ridge Associated Universaties, December 8-11, 1969. U.S. Atomuc Energy Commission Symposium Seties 20 (June 1970), pp. 49l-507.

3. Feinstein, A. R. Cinical Judgement. Williams and Wilkins Co., Baltimore, 1967, p. 271.

\section{Human Epidemiology}

\section{EPIDEMIOLOGY OF ENVIRONMENTAL EFFECTS}

\section{WHAT CAN BE LEARNED ABOUT LOW-LEVEL RADIATION EFFECTS FROM THE RADUM CASES?}

\author{
R. E. Rowland
}

\section{Argonne National Laboratory}

The siudy of the effects of internally deposited radium isotopes began long before accelerator or fission-produced radjoisotopes were created. Human exposures from radium, acquired ejther through induslial exposures of jatrogenically, have provided a great wealth of information on the effects of radiation on man. Howerer, most of the emphasis has been placed on the effects of hight levels of radium.

Exposure to radium, however, has produced a complete spectrum of levels of internal contamination. The exposed population consists, therefore, not only of the high level cases where the majority have died as a result of their exposure, but also a large number of low-jevel cases where few, if any, consequences of the radiation exposure have been detected. 
Since the formation of the Center for Human Radiobiology within the Radiological Physics Division of Asgonne Laboratory, we have acquired case records for most of the radium cases that have been located within this country. From some 2000 records, we have identified a group of 777 cases who have a measured body burden, and for whom to1al doses have been calculated. These cases experienced a total of 71 malignancies presurned to be radiation induced.

Various dose response functions have been fitted to these data. The function yislding the most satistactory fit for the entire range of doses is of the form

$$
\text { Tumor Incidence }=K\left(\text { Dose }^{2} \mathrm{e} \cdot \text { Dose } / \mathbf{D}_{0}\right. \text {, }
$$

where the Dose is the average skeletal dose.

For this discussion the region below 1000 rads, where there are $\$ 84$ cases with no malignancies to date, as of most interest. Assuming that a linear response applies in this region, these is a $90 \%$ probability that the relation of incidence to dose is

Tumor Incidence $60.3 \%$ per 100 rads.

Future studies on the population of radium cases will include:

1. All possible efforts to increase the number of cases ayailable for study.

2. Complete follow.up of all living cases for the remainder of their lifetimes. Of our population of 777 cases, some $\$ 80$ are alive today, most of whom have now carried radium within their bodies for over 40 years.

It is the alpha-ray dose to the soft tissues adjacent to bone which is usually considered when evaluating the effects of internaly deposited radium. The following features, usually ignored, are also to be considered:

1. Most of the radon formed diffuses out of bone into the blood stream, and thus throughout all organs of the body. Radon decay mey thereby result in the irradiation of all organs of the body.

2. The radusn daughter products which do rernajn within bone emit, in addition to aipha particles, beta and gamma radiations, which effectively deliver a small tose to all of the contents of the manow cavity and surrounding tissues.

Thus the fiving radium cases have experienced not only intense alpha radiation adjacent to bone, but continuous lowlevel irradiation of all the tissues. The study of this population, therefore, may yield a background of information applicable to low-level radiation exposure to the entire body.

\title{
EPIDEMIOLOGY OF ENYIRONḾENTAL EFFECTS
}

\author{
P. E. Sartwell
}

\section{Johns Hopkins School of Hygiene and Public Health}

It is difficult to think of epidemiological studies of low ilevel radiation effects which do not inwolve une follow-up of exposed populations, a topic allolted to another group. Two kinds of situation have provided most of the direct information on human effects. These are occupational exposures, and diagnostic or therapeutic exposures. Occupational groups which have yielded valuable information include the Colorado plateau uranium miners, radium workers, and radiologists. A common deficiency in such studies is lirnited information as to dosage. Occupational risks have probably become much smaller than heretofore.

Medical exposures which bave been well studied include $X$-ray pelwime ry in pregnancy, and treatment of ankylosing spondylitis. Other situations have been less well investigated. In particular, lubejculosis patients who received pneimothorax treatment in the nineteen-thirties and forties should be followed up, since they Jecejved heavy fluproscopic exposuses. Suitable controls would be patients with simalar lesions who could not receive pneumothorax. Such a study would be difficult because of the long elapsed time, but nevertheless offers promise.

No information is arailable, to my knowledge, on the effects of living in sites where natural background radiation is very high. India and Brazil are said to have such regions. It would seem feasible to make such studies, which might yield information as to possible increases in mutations, congenital defects, intrauterite death, cancer incidence and general mortality. 
More can be learned about the tongevity, reproductive experience, diseases and causes of death of radiologists in comparıson with other medical specialists In particular, we need to learn if the excess mortality which we attnbuted to occupatronal exposure is still in evidence Two studes-one based upon a registry of radiologists and pathologrsis, the other in analysis of mortaluty experience of severat medical specialist groups-ape under way to answer these questions

The investigations mentioned above are of the longitudinal of cohort type Another approach is to select a disease suspected of beng radution induced and conduct a case-control study This approach has been used effectively in sludies of leukemia, lung, breast and ceruical cancer and other diseases 11 permits the estinnation of relative risks of 2 solected disease among those who have had a particular exposure, such as radiation

The acceleration of aging by tadiation is a phenomenon established in anumal experyments but not yot clearly indusited in man It is perhaps the most important, as well as diflicult, low-level radiation effect to evaluate In addrton to cunucal evidence, an excessuve age-spectic mortality beyond age 45 atiributed to cancer, atterioselerotic heart disease and some other causes would be ovidence for acceleraied aging in exposed human populations

In epiderniologic studjes it is important to take account of other environmental and host qualities which may also influence disease incidence An example of this is the importance which crgarette smoking appeared to extrt in amplufyang the effect of raduation in unducing lung tancer of uranium miners

\title{
EPIDEMIOLOGY OF ENVIRONMENTAL EFFECTS
}

\author{
Raymond Seltser
}

\section{Johns Hopkins School of Hyguene and Rublic Health}

The spectfe charge to each participant of thus conference was 10 bring a concise statement of his Yiews about ways to improwe the estumation of low-level effects in human populations It was to deal explicitiy with the following two pounts 1) assessment of the present state of knowledge and conidence and 2) exaluation of future courses of aclion

The type of radiation hazards from "envisonment effects" can be classified according to the source of the radiation exposure, $1 \mathrm{e}$, alr, water, or sol] Jt is relatively easy at this point to assess the present state of knowledge concernug low-level effects attrubutable to atr, water, or sol exposures The controversy over the interpretation of vital statıstics-and the need to rely on such imprecise measurements at all in attenipting to detect raduation effects in human populations-is an undictment of the fallure to develop and maintan adequate study populations which might serve as indicators of these effects There is limited knowledge ayaliable from the Marshallese data and the Nevada test data, bot these are so scanty, controverstal, and selectwe as to be almost worthless for specticic inferentıal use

How, then, should this problem be attacked? What can we do now and in the future ${ }^{9}$ i believe that there is the need for the development of a National Environmental Effects Survellance Center, charged with the responsibulity of

J Manitoning through appropriate sampling schemes for the existence of "high risk" areas andfor populations where the levels of any envionmental toxic agenl (whether it is radiztron or other pollutant) exceeds an establushed munumum,

2 Survellance of such hugh rask areas and populations, developing whatever specific studes are needed to determune dose-effect relationships between the "agenl" and the host

I belreve that such studies and such populations must ro longet be allowed to develop at the "whims" of undwidual investıgators All such identulied groups should be considered "national tesources" and as such, follow-up should be under the angs of some central group It is likely that much of the actual work on the se groups could be carried out by unversity personnel or other unterested groups under cantract to the central unit

I cannot overemphasize the importance of attempting to the in the survellance for radiation effects with sumblar activities for other biological effects unduced by other environmental hazards The techniques of study and the problems of follow-up are sumlar for all these agents-even thaugh each siudy would require different types of scentufic and technical expertise on the study team The common denominator, however, is the epidemuologist whose forte is the techniques of hypothess testing in human population groups 


\title{
ROIE OF THE RADIOBIOLOGIST IN SETTING GUIDELINES
}

\author{
A. R. Tamplin
}

Lawrence Radiation Laboratory

For the purpose of setting gutidelines for the exposure of individuals by ionizing radiation, the reasonable publichealth approach is to use a linear extrapolation beyond the point where tata exist. This, it can be said, is my opinion and it involves certain value judgments that lie outside my scientific discipline. With this I would agree.

At the same time, 1 think this itlustrates the role of scientists in setting the guidelines. His role, as a scientist per se, stops where valid scientific evidence ends. At that point he has one additional inpul and that is to define the nature of the expetiments, the lime required and the money needed to resolve the uncerlainties.

I think the present data are sufficient 10 set the guidelines. To do further experiments for the sole purpose of sefting the guidelines would appear to be counter-praductive. For the most part, the study of low-level radiation effects entered the baroque period some years ago. By this I mean that the experimental approach has been to study larger groups of animals at Jower dosages. These studies now show linearity down to 10 rads. Further exterision solely for guideline purposes would seem unwarrantted.

The future of radiobiology would seem to lie in different pursuits such as investigating the mechantism of radiation carcinogenesis. Hese it seems to me that more experiments involving synergism and co-carcinogenesis should be underlaken. I think the same thing applies to the genetic effects, for example, investigating the different behavior of the mouse ocxytes. Also more effort should be applied to the rale of the chromosome alterations in both carcinopenesis and genetics. The newer techniques for sludying thromosomes wopuld suggest that this area is ripe for detailed study both in animals and man.

\section{Physics and Models}

\section{DOSIMETRY STANDARDIZATION-COOPERATION IN LATE EFFECTS RESEARCH IN EUROPE}

\section{J. J. Broerse}

\section{Radiobiological institute, TNO}

Progress on the estimation of low-lewel radiation effects requires large-scale experiments and long-1emm commitments of personnel and facilities. Such requitements are in general beyond the scope of an individual laboratory, because of limitations with respec1 to finances and technical facilities. In the past, the lack of standardized experimental material and variation in methodology and in quantitation of end points, have made interlaboratory comperisons extremely difficult. A solution to these limitations, providing the possibility of more rapid advances in the field of late effects studies, has been Jound in a coordination of projects of several European laboratories organized in an European Late Effects Project Group (EULEP).

A cooperative research program requires the standardization of methods used in the participating laboratories [1]. A few areas can be distinguished where the standardization of methods is of paramount importance, namely, dosimetry, experimental animals, and special auxiliary methods used in experimental and clinical studies. Such a standardization will facilitate the comparison of results obtained as well as their evaluation and interpretation.

For a quantitative assessment of the effects of external irradiation, the exposure procedures have to be standardized and the absolute dosimetry has to be consistent within the participating laboratories. For internal irradiations, it will be necessary that the participating laboratories apply the same models and the same phystcal and biotogical data for their dose calculations. For the standardization of dosimetry in these laboratories, a special dosimetry committee has been appointed to assist in dosimetric problems and to suggest improvements in existing methods. At present the committee has given recommendations for the standardization of $\mathrm{X}$ ray dosimetry [2] , and is carrytng out dosimelry intercomparisons. A mail service of thermoluminescent tosimeters has been organizedi. The preliminary results of the EULFP $X$ Jay dosimelry intercomparisons are shown in Table 2. 
TA aLE خ. Preliminary Results of X Ray Dosimetry Intercodiparison

\begin{tabular}{|c|c|c|c|}
\hline Institute - blind coded & 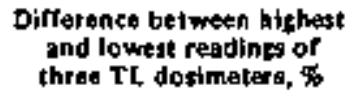 & $\begin{array}{l}\text { Mean value for tirst } \\
\text { intercona partson, \% }\end{array}$ & $\begin{array}{l}\text { Mean valua for recond } \\
\text { intercomparkon, } 4000\end{array}$ \\
\hline $\begin{array}{l}\text { A (Rijswijk) } \\
\text { C (Eilthoren, standardized) }\end{array}$ & $\begin{array}{l}0.4 \\
2.1\end{array}$ & $\begin{array}{r}102 \\
90\end{array}$ & $\begin{array}{l}101 \\
101\end{array}$ \\
\hline (OOn NES and NPL) & 0.9 & $\begin{array}{l}98 \\
97\end{array}$ & $\log _{91}^{100}$ \\
\hline $\mathbf{E}$ & 1,9 & 97 & 102 \\
\hline F & $\begin{array}{l}2.9 \\
1.7\end{array}$ & $\begin{array}{l}116 \\
106\end{array}$ & 104 \\
\hline 4 & 4.5 & 99 & 98 \\
\hline$k$ & 0.1 & 101 & 100 \\
\hline L & $\begin{array}{l}2.1 \\
4.9\end{array}$ & 107 & $\begin{aligned} 95 \\
114\end{aligned}$ \\
\hline $\mathbf{N}$ & 0.6 & 91 & 90 \\
\hline O & 0.5 & 105 & 101 \\
\hline $\mathbf{P}$ & 2.3 & $\mathbf{8 1}$ & 17 \\
\hline $\mathbf{Q}$ & 1.5 & 103 & 110 \\
\hline
\end{tabular}

\title{
References
}

1. EULEP (European Late Effects Project Group). Proposal for the performance of a cooperative research project on late somatic effects of jonizing radiation in mammalian organisms, to be publighed in 1971.

2. EULEP. Recommendations for the standardization of $X$ ray dosimetry, to be published in 1971 .

\section{A STATEMENT ON LOW-LEVEL EFFECTS IN HUMAN POPULATTONS}

\author{
H. H. Rossi \\ Columbia University
}

I believe that we are in the process of formulating the basic nature of the radiation tesion in the mammalian cell to the point wheje the kinetics of a particular inactivation or injury can be defined in terms of two or three characteristic quantities. Short-term research goals should be concerned with the measurement of these parameters in order to achieve the ability to predict effects at low doses and, in particular, to identify the magnitude of the linear term in the relation between dose and cellular effect. Reserrch suitable for this purpose is concerned with an assessment of the effects of radiation quality and of dose rate, particularly at low doses. An important larger experiment should be a comparison of the effects of chronic exposure of animal populations to high $\left({ }^{\circ} \mathrm{Co}\right)$ and low $\left({ }^{30} \mathrm{Tm}\right)$ energy gamma rays and to neutrons $\left({ }^{252} \mathrm{Cf}\right)$. This should provide many of the needed data, even with observations at doses that considerably exceed permissible levels. Extrapolations or mathematical analysis of the dose effect relation for any one racliation are likely to be slerile or misleading.

The biophysical approach mentioned above provides only a limited pragmatic understanding of the action of radiation on the cell. It is unlikely to solve such fundamental problems as the biochemical identity of the radiation lesion or the interrelation between cellulat and tissue effects. The answer to the first of these questions is not immediately requined for radiation protection. The answer to the second has considerable bearing on whether permissible doses based on cellular response are too low but not on whether they are too high, since injury to more than one cell must exhibit a dose-response relation in which linear terms are suppressed or absent. To overestimate radiation hazards might be as harmful to progress as to underestimate them. Thus restarch designed to olucidate the relation between ceilular injury and pathological response to radiation should have high priority. 


\title{
THE DOSE-EFFECTIVENESS FUNCTION (DEF). DEFINITION, DATA, AND A CYTOGENETIC MODEL
}

\author{
G. A. Sacher \\ Angonne National Labortiony
}

The DEF is defined for each end point as the functional dependence of yield on dose, with yioid expressed per unit dose. The validation of each empirical DEF estimate depends on derronstration that the dejived curve is not distorted by interactions with other parameters.

Analysis of life shortening data for rodents given single, fractionated or lifetime exposures to $\gamma$ rays, $X$ rays or fission neutrons establishes the following properties for the DEF: 1) over a $\gamma$-ray dose range extending from aboul $10 R$ up to about $100 R$, the DEF incresses as the first power of the dose; 2) below $10 \mathrm{R}$, the DEF is constanl, with a nominal value of $0.0004 \mathrm{~K}^{\prime}$, above $100 \mathrm{R}$, the DEF rolls over to an upper plateau with a value of about $0.003 \mathrm{R}^{-1}$, so the high- and low-dose effecliveness values are in ratio of aboul $\left.8: 1 ; 3\right)$ the DEF for fission neutrons is nearly constant over the entire range, so the reciprocal of the DEF is approximately the RBE function for fission neutrons relative to gamma zays.

It was conjectured that the middle and upper branches of the DEF are due to cell injury and death arising from inviable rearrangernents of broken chromosomes. A computeraided mathematical analysis of chronosome breakage and reunion is being developed which permits the kinetics of these processes to be modeled. The computer model can deal with $\mathbf{4 0}$ or more simultanecus chromosome fragments per cell. The first cases modeled are found to fit the two upper branches of the DEF when the two adjustable paramelers are assigned valuts consistent with the data of cell radiobiology.

Further sludy of the propertios of DEF's for various end points, and of the cytogenetic theory, should be given priority becsuse they promise to provide a basis for evaluating the parameters of the low.dose branch for effects on man. Some first objectives at the phenomenological level are: I) measure DEF's for various somatic end points, especially leukemis, making use of the relation be (ween DEF and RBE curves; 2) in particular, delemine in each case whether a low.dose branch exists, and whether it has a consistent ratio to the high dase brench (this ratio is so far known for only one end point); 3) determine the DEF's for species differing in sensitivity, and their parametric differences (e.g., guinea pig and mouse DEF's differ only in the recovery rate parameter); 4) seek further evidence on the quantitative relation of somatic disease and death to cell death; and \$) pursue the relation of cell death to chromosome lesions, especially the mechanisms of the first-power dose dependence at low doses.

A great effort will be needed to match the chromosome sberrstion theory to the complex phenomenology of the cell cycle, but significant advances can be made independent of that development. For example, the theory has already suggested new experiments on the effects of fractionation and neutron-gamma mixtures, which may have important consequences.

\section{Exposure Guidelines: The Process}

\section{THE DEVELOPMENT OF EXPOSURE GUIDELINES}

\author{
Lauriston Taylor
}

National Academy of Sciences, Washington, $D . C$.

A numerical value for a standard of effect implies a knowledge of the effect produced at a given level of stress, and that both effect and stress are measurablè. Al modesl doses of a few tens of rads delivered in a short time period the statistical identifieation of certain cause-related effects becomes possible; no observations have been possible for levels below a few rads. Because of this, many questions arise.

Any protection specification requires an indication of the object to which the standard applies. If the object is raan, is it all ment, and are wo by such prolection tepriving him of something he needs and desires-like more life at some level of health and comfort, or perhaps just some more comfort, or something material? And who 
evaluates his needs and desires and decides uppn the level of the rulfilment? These questions have to be answered before we can assess the value of our state of knowledge because unless, and untrl, we have some basss for a relationshıp between whom we ate proleclıng and what we are protecting aganst, we are largely un an atmosphere of personal opinion and we can more easily settle the problem by yoting-except that a consensus in ignorance does not produce wisdom

Another problem is the defintion of what an "effect" is and whether it can ultimately be shown to modily man's "way of life" of that of hus of ispring

It is reasonable to suppose that an allowable exposure of population groups to ionizing radiation ornginating from a controllable source would be at some level less than thal causing an observed effect For exposures above the munumum, $\mathrm{E}_{0}$, to cause an observed effect, there are various dose-effecl relationships that may vary wilh the effect and the manner in whuch the dose is deijvered However, the population doses, $E_{p}$, for which there is concern, are a small fractıon of $\mathrm{E}_{\mathrm{b}}$. doses generally of the order of that from natural radiation $\mathrm{E}_{\mathrm{n}}$, or much less $\mathrm{E}_{\mathrm{p}} \gamma_{2} \mathrm{E}_{\mathrm{n}}<\mathrm{E}_{\mathrm{a}}$ The allowable dose might be arbitrarily set as low as zero, where there is clearly no direct or indirect benefit to anyone $A$ level above zero would be set in consideration of possible needs, benefits, risks and costs The question is how to evaluate or postulate the effects or rasks in the dose region below the level of $\mathrm{E}_{o}$ in which no cases are lukely to be found within the forseeable future How then is an allowable dose level sel?

The method used in toxicology is to make no assumptions about dose effects in the regron where there are no observed effects and choose an allowable level at some fraction of $E_{0}$ It is a sumple "safety factor" method One alternative would be to postulate a linear dose-effect relationship in the dose range between $\mathrm{E}_{0}$ and żero dose, disregarding repair and recovery These is little foundation based on observalions for such an extrapolation, and snnce there is some biological repart and recovery any such plot would, at most, represent extreme upper values for effect Such an extrapolated curve, alone, is not only valueless but seriously misleading when used as a basis for calculating or predicting radiation risks, injuries or deaths

Thus, netther the safety factor nor extrapolation method can be used for quantitative evaluations of exther effects or risks The man virtue of the second method is that the extrapolatıon may provide a useful line of departure for the study of effects when new techniques or large statistical samples may yield some signilicant data in the low-dose segion lin the meantime for doses $\left\langle\mathrm{E}_{0}\right.$ it must be clear that the effects have faded into insignuficance A definulion of "insignificance" is essential

\title{
Chairman's Committee Report
}

\section{ON THE DOUBLING DOSE CONCEPT}

\author{
C W Mays
}

\section{Universty of Utoh}

By analogy with the inducton of benetsc mutations, some Indivduals $[1,2]$ have assumed that the uncidence of radration-induced cancer is directly proportional 10 both its "ratural" incidence and the radration dose

$$
I_{r}=I_{0} \frac{x}{D}
$$

where

$$
\begin{aligned}
& \mathrm{I}_{\mathrm{r}}=\text { radiatton-unduced unctdence } \\
& \mathrm{I}_{0}=\text { natural uncidence } \\
& \mathrm{x}=\text { radiation dose } \\
& \mathrm{D}=\text { doubling dose (assumed constant) }
\end{aligned}
$$

However, the same indryduals proposing the above retationship have indicated that the so-called natural incidence is not a fuxed quantity, but can be influenced by vartous factors such as country of resudence [1], cigarette smoking [1], exposure to asbestos [1], and background radiation [2] For example, they present data indecating that for radiation-induced lung cancer, the incidence per rad is about 10 imes higher in cigarette smokers than in nonsmokers, and ascrube this to the lofold hogher natural uncitence among the cugarelite smokers [I] 
Furthermore, they claim that the average background of about $0 \mathrm{I}$ rad per year causes about $3 \%$ of the naturally-accurning concers If this were true and if the dose-response were Jnear, then from thss factor alone the predicted natural incidence in some regions should be 4 tumes averago, since background radiation in some inhabited parts of the world ranges up 10 about 10 cads per year, which is 100 .fold hugher than averaige [3] Predicted natural madence for such regions of hugh background

$$
\begin{array}{ll}
\text { Radiation unduced } \cong 100 \times 3 \% & =300 \% \\
\text { Nonradiation induced } & \equiv 100 \% \\
\text { Total ngtural incidence } & \equiv 400 \%
\end{array}
$$

Thus, (from Equation 1) the increased incedence per additional rad in such regions of high natural background is predicted to be about 4 times greater than of background-equivalent radiation had been artuficially given This suggests that Equation 1 is inconsistent sunce tissues cannot distungush between radiations which differ only in their natural ys artuficial orıgin:

It seems more consistent to assume that the addituonal uncidence (dI) from additional dose (dx) is proporlional to the tolat incidence (l) which would resuli from the previous radiation doses and natural causes

$$
\frac{d}{d x}=k I \text {, }
$$

where (k) is a constant of proportionality The solution to Equation 2 is

$$
J=I_{0} \mathrm{ekx},
$$

where natural incidence $\left(I_{0}\right)$ is assumed constant for lixed conditsons Since the total incidence (I) equals radiation-induced incidence $\left(I_{r}\right)$ plus natural incidence $\left(I_{0}\right)$,

$$
I_{r}=I_{0}(\mathrm{ckx}-1)
$$

In Equation 4, the predicied incidence of radiation-induced cancer increases not linearly, but as an exponential function of dose However, the higher the natural ineidence, the more closely the exponential Equation 4 approaches a tunear relationship, as has been shown in a more detailed analysis on this topic [4]

But one must cealize that the fundamental mechanisms by which rediation induces cancer may be quite complex, and any relation as sumple as Equation 4 should not be expected to describe accurately the actual incidence over a wide dose range For example, it must break down at very lugh dosos because of the radiation killing of potent,ally malıginant cells It may, howeves, prove useful in testing hypotheses against experimental data, and it may give unsught into alternatuve models wheh may more closely approxumate that elusive goat called reality

I am grateful to Austin Brues for first pointing out at this conference the nonlunear inlerpretation inherent in the "doubling dose" concept, to Roy Albert for ssking me to write it up, and to George Sacher for including it in these proceedings

\section{References}

1 Gofman, J W and A H Tamplin Mayor fallecres in the AEC staff comments on the Gofman-Tamplin papers and congressional testumony Envuronmental Effects of Producing Electric Power, Hearıngs of the Joint Committee on Atomic Energy, Part 2, Vol II (Jan 27-30 and Feb 24-26, 1970) pp 2] l3-2] 27

2 Gofman, J W and A.H Tamplun, Low dose raduation, chromosomes and cancer Envoronmental Effects of Praducing Electre Power, Hearugs before the Jount Commuttee on Atomic Energy, Part I, (Ocl 28-31 and Noy 4-7, 1969), pp 641-652

3 Penna-Franca, E, J C Almevda, Johanne Becker, et al Status of inyestigations in the Braziltan areas of high natural raduosctivity Health Phys $11,699.712$ (1965)

4 Mays, C W A nonlinear interpretation to the doublung dose concept Research in Radiablology, University of Utah Report C00-1 19.244 (March 1971, in press) 


\section{Documents Distributed during the Conference but Not lnciuded in These Proceedings}

Abrahamson, S., P. Gullifor, E. Sabol, and J. Voigtlander. The induction of translacations in mature Drosophila oocytes over a dose range of $10-500 \mathrm{R}$ of $\mathrm{X}$ rays.

Kellerer, A. M., and H. H. Rossi. RBE and the primary mochanism of radiation action.

Goldman, M., N. H. Hetherington, L. S. Rosenblatt, and L. K. Bustad. Quantitative evaluation of dose-effect relationships following exposure of dogs to internal emitters.

Rowland, R. E., P. M. Faila, A. T. Keane, and A. F. Stehney. Some dose-response relationships tor tumor incidence in radium patients. 


\title{
RAPPORTEURS' ACCOUNTS
}

\author{
Mammalian Radiobiology
}

\section{SYSTEMIC AND PHYSICAL FACTORS}

\author{
J H Storer and $1 \mathrm{M}$ Yuhas
}

Ouk Rudge Natwonal Laboratory

The session on systemic and physical factors covered two broad questions the role of anumal expenmentation in the estımation of low-level radıation hazards for man, and the type of anumal experumentation which would most adequately fulfill this rele Since animal experimentation will not in itself allow us to evaluate radiation standards, its role is largely that of establıshing general principles which relate to the overall problem Experıments designed to test smaller and smaller doses of radiation thuough the use of larger and Jarger populations of aninals should be avolded, owing to therr lack of generalty, unless specific hypotheses afe being tested whxch go beyond "late effects surveys" In ordes to be relevant, anımal experumencation shoutd concern utself with mechanısms or processes which are known to be specres-independent, or which can be related logically to biological characteristics for an interspecies comparison

Specific areas whuch merı further investigation unclude

I the role of the immune system in the control of radiation-induced cancers, especially un the low-dose-rate range,

2 the quantitative relationships which exist between acturated viruses and the resultant cancers, I0rn and krypton

3 the toxicology of internal emutters which may be encountered by man, including int-

4 the relationship between total dose, dose rate, and the incidence of late effects, includong aralyses of the role of single and multiple event phenomena in the induction of specific disease entilits

\section{CARCINOGENESIS}

\author{
A M Brues and $C$ f Hoilander
}

\section{Argonne National Laboratory and Expermental Gerontology Unt, TNO}

The opinion was expressed that normal effects are accelerated by treatment, more attention should be paid to morbidity than to mortality, iffe shortening is not the most valuable parameter unless it is related to specific death rates for specific diseases Some tumors (lung adenomas) are present for a long tume in living anumals so that the morbidity rates are not estimated by autopsying animals as they dee The plot of the logarithm of the ralt of tumor morbidity aganst lime shows a decreasing slope later in life The decrease occurs later and us less marked un palhogenf ree mate

The carcinogenc process seflects a competition of two factors tumor unduction in ceils and kulang of cells It has been useful to use moncenergetic pons to study caranogeneic action, as this controls the site of radiation action The question of duect effect has been sludied by skın Iransplantation, tumors ane shown to arıse from the irradiated skin, and not from the skin of the uniriadiated recipient, even after a thisd transplent generation

Thefe are various studes, using cazcinogens in general as well as radiatıon, which indicate that host tactors are important as well as the ceils that are the origin of the tumor This 18 suggested by viral carcinogenesss and the role of ammune factors, and by plastic carconogenesss, whech has not been shown to be enhanced by radiation, and which has resemblances to transformation of celi cultures and to the conditions preventing differentiation of embryo organ cultures An example of a host factor in co-carcinogenesis is the inhubition of ciliary action in the lung by tobacco smoke, favoring retention of inhaled particles Care must be taken to disıingush between carcinoma un stu, bengen tumors and invasive malignancy

It was noted that the evidence for co-caranogentess by smokung in uranum muners is not complete at present The existence of chemical agents in miners, in addition to radon, was indreated 


\title{
LARGE ANFMAL STUDIES
}

\author{
Marvin Goldman and S. M. Michaelson
}

\section{University of Collformin and Untversity of Rochester}

The discussion relating to reseatch on large anımal radiation effects suggests that they provide valuable model systems extrapolatable to man. For example, there are data which show that dogs manifest a spectrum of responses to ${ }^{226} \mathrm{R}$ a similar to what has been reported for man. A consistent finding in large animal studies is that the dose effectiveness for cell or tissue "injury" and cancer incidence is nonlinear in each study in which all the data are included in the analyses. The discussion pointed out some discontinuitles or deficiencies which appear to be related to (I) the nonuniJorm distribution of dose over time, and over the cells at risk and the tissue or organ system under study, and (2) the uncertainty about the fraction of the absorbed tissue dose that is unavajlable to cells at risk, either because the cells wete previousiy kulled or aze not in the range of the ionizing events. An additional example was a discussion of the nonuniformity of local dose distribution and tissue response of lungs of dogs following inhalation of high tevels of ${ }^{239} \mathrm{Pu}$.

It was. also noted that lung pathology, nol radiation related, also ofter manifests a nonuniforn distribution throughout the organ. These observations may be showing us valuable data on the actual distribution of types of cels at risk. In this context, some of the radionuclide effects studies are of particulat value for determining the distribution of cells al risk by evalualing cell injury or death, and incidence of neoplasms spatialiy and temporally, with regard to their specific dose rate pattern. The data do not suggest unique radiation carcinogenetic effects in tissues nol being directly irradiated.

The problem of interspecies compatisons is also related to the above. It would appear important that some species scaling is possible, and data exist for cell, tissue and organ systems receiving comparable dases of codiation, independent of and parallel with such data as relative body mass, metabolism and lifespan. The use of systems physiology, based on various levels of biological organization in several anımal species with specific and weliknown attributes, is invaluable in extrapolation to possible human hazards from radiation.

There is an obvious need to carefully extract and evaluate the costly and painfully obtained data that already exist on radiation effects in large (long lived) animals, so as to assure the best possible analyses in relation to assessment of linear ys. nonlinear response characteristics.

\section{TLSSUES AND CELLS IN VIVO}

\section{E. B. Darden, Jr. and R. J. M. Fry}

\section{Oak Ridge National Laboratory and Argonne National Laboratory}

The first tissue considered was the mouse lens, which can be examined serially to tecord the development of tiny opaque defects (termed flecks) which electron micrographs suggest to be defective portions of single lens fibers. Normal fibers are produced by proliferation of the lens epithelial margin, throughout life at a declining rate. Progeny cells migrate to the lens equator and mature into adult fibers. The time interval (six weeks) from division to maturation is equal to that from irradiation to an increase in flecks, evidence that the site of injury may be the lens germinal cell. Flecks in the nonirradiated controls begin to appear at 13 weeks of age and increase with tirne, suggesting the presence of abnormal but viable germinal cells in the normal lens epichelium. If irradiated at six weeks of age, mice reveal fleck counts which also appear at 13 weeks of age, but increase at a faster rate. Dose dependent RBE values have been obtained, being $5 S$ for $0.5 \mathrm{rad}$ of $0.43 \mathrm{MeV}$ neutrons and 6 for $5 \mathrm{rads}$ of $14 \mathrm{MeV}$ neutrons. X-ray dose response appesis sigmoid, whereas $12 \mathrm{rads}$ of $\mathrm{X}$ rays produced a detectable effect, $4.5 \mathrm{rads}$ did not. The incidence of flecks is being studied in the Marahallese and several women who received 175 rads from fallout radiation in adolescence have shown an incidence of nlecks above the control level. (A generally accepted ratio of Jens radiosensitivity in man: rabbit:mouse is $1: 4: 16$, zespectively.)

The interspecies comparison appears to show that the larger eyes are less susceptible to induclion of lens opacities. The reason for the difierences in sensitivity are unknown, although it was suggested they may be related to differences in growth rate and therefore proliferstive rate.

Studies of the relationships of cell killing, chromosomal abnormalities and the incidence of 
opacities on an interspecies bass appear a possibulity There would be the advantage that the results would be almost Independent of cellular responses elsewhere in the body The system is also useful in providing expenmental data for comparison to theoretreal models The second sensitive system was the mouse zygote Irradiation is given shortly after tumed mating. in the early pre-implantation stage Sixieen days later the uter are examned Wilh relative embryo survival as the end pont the effect of $<5$ rads of neutrons can be delected Survrval at higher doses appears to be exponentual, at teast to 20 rads, with a $D_{0}$ of 18 rads The $R B E$ with respect to $X$ rays is about 4 over this dose range The unportance of interspecies studies was emphasized for the determunation of the relationship of changes un cell systems, such as colony-forming cells of the bone marrow, to life shortening There are marked spectes differences which are likely to be of importance in the elucidation of the abulty for repair and recovery after acute exposure and chronic low dose exposures An understanding of these specres defferences would appear to be necessary for extrapoiation of data from small anımals to man Adequate comparative studies are difficult to carry out, and for some time it will be necessary to rety on small anjmal experiments The advantage of the mouse experiments is that the determination of loss of stem cell populations, or thesr ability to respond to stress could be done as a function of age and radiation exposure hisiory Furthermore, correjations between the functional capacity of the marrow probferatuve cells and disease incidence could be tested Some prelimunary data sugeested that there was a marked deminution (30-60\%) in the number of CFU's in the femoral marrow of old muce that had been exposed to midlethal doss at 100 days of age While there is considerable information aboul recovery of marrow stem cell population over a relatively short time span after irradiation, bttle is known of the very late effects on the number of stem cells in prolıferative populations The possible relatuonships of such changes to life shortening and tumor incidence are not known The effects of several other environmental factors may, particularly, influence the bone marrow cell population and wll have to be known for interpretation of results of low-level irradiation studes The question was posed whether an understanding of differences in organ and species sensilivity for the induction of tumors could be derwed from expesiments in which whole-body exposures were given, even with the additsonal information from local uradiation, or will it be necessary aiso 10 carry out in vitro experuments to detejmine an index of transiomation for the appropriate cells? No answers were offered References were made, both un this and other sections, to the unmune system and its relatson to tumor incidence but no fata on the changes in the immune competent cell system as a late effect were presented

\title{
Genetics and Cellular Radiobiology
}

\section{GENETICS}

\author{
Seymour Abrahamson
}

Unversity of Wisconsin

Dr Crow spoke on the problem of assessing spontaneous detrimental mutations rates in Drosophula These mutations are measured in a statistical manner by their action of decreasing viabulity They may represect sungle gone mutations with a large effect, or a large number of mutations, each with a small effect These mutations arise spontaneously on a given test chromosome at between $02 \%$ and $03 \%$ frequency At equilibrium they ace at $10 \%$ frequency Thus the average detrimental mutatıon will persist for approxımately 40 generatıons Recessive lethal mutatons for the same chromosome arse spontaneously at a $05 \%$ frequency and at equilbrim exist at about 25\% frequency and lukewise persist for about as many generations as the detrumentals Therefore, both the recessive lethals and the recessive detrimentals exert thesr effects in heterozygous condition, and the elimination of both classes results from the slyght dominant action of these recessive mutants It follows that a recessive deinmental exerts as much heterozygous effect as a recessuve lethal The defficulty of obtaunis equivalent data in man was stressed

Data were presented on the induction of chromosome aberzations in Drosophula oocytes by low doses Aberfations increased lunearly between 10 and $50 \mathrm{R}$ of $X$ rays, and quadratıcally between 50 and $500 \mathrm{R}$ 1n the study of sox-Junked recessive lethals in oogonis at $0,20,100$, and $500 \mathrm{R}$ doses, with some 77,000 chromosomes analyzed, none of the treatments was sugnificantly increased above the control rate [n revewing other workers' rosults on spermatogonja in Drosophila at doses below $500 \mathrm{R}$, it again becomes evident that there are few if any data whoch demonstrate any sgnuficent increase in the arduction of mulations Thus, even in systems which optumize the 
detection of mutations, the difficuly of demonstrating their induction at low doses in the important cell stages for estimating hazards becomes very evident.

F2 data were presented on the induction of detrimental mulations in the mouse when spermatogonia are irradiated. The detrinental effect was measured as an incremental componenl of mortality within the first 21 days after birth. Grahn described this effect as being induces at a rate of $1.7 \times 10^{6} / R$ day. This is the first dernonstration of transmitted detnmental mutations in irradiated mammalian systems. Subsequently the discussion sentered upon the proposal (see his position paper) to monitor mastet samples of the U.S. with well-determined genetic and somatic endpoints. A large segment of mammalian radiation genetics was unfortunately unreviewed because of the unexpected absence of one of the panelists.

\title{
CYTOGENETICS
}

\author{
A. B. Reiskin \\ The University of Connecticut
}

The position papers on cytogenetic effects I) explained the great difficulty in obtaining statistically significant cytological differonces at low levels of jadiation, and 2) ponted out the relations between chromosomal effects and other effects in radiobiology, and possible synergisms with other agents.

One of the main points disoussed concerned the use of automated chromosome scoring to increasto the resolution of the analysis. In generel, radiobiologists are hopeful that such techniques will aid in the evaluation of low level effects. It was pointed oul, however, that the biophysicists who are involved in the development of such automated machines are often less sanguine. Their projections for the cost of analysing each cell seem lo preclude . the use of machines for scoring chromosame aberrations after irradjation of multiceliular organisms. At this meeting, however, several people expressed the opinion that the cost estumates will prove to be wrong and the the cost per ceil will reflect the state of the art and become infinitesimal.

The central role of chromosomes as sensitive targets whose damage underlies many radjobjological phenomena was illustrated in that two separate models were presented relating the kinetics of tumor induction andfor cell killing to the kineties of aberation formation.

Among other intriguing notions briefly mentioned was the possible implication of radiation chromosome breakage in virus-induced tumorigenesis. It has been proposed that breaks in DNA are necessary for incorporation of the vinuses. The curves for the induction of multibreak chromosomal aberrations are linear at very low doses. Data were presented showing that this is true for othes multitarget radipbiological phencmena, such as cell survival. The mechanisms involved in these low-dose linear components of chromosome Jearrangement and cell kiling are not adequately known, and further work is needed.

\section{CELLULAR RADIATION BIOLOGY}

\author{
G. F. Whitmore \\ Ontorio Cancer Institute
}

It is likely that some of the information required to evaluate the bazasds of low doses can only be obtained from studies involving humans or laboratory mammals, but considerations of cost and convenience suggest that where possible such information be derived from studies on mannalian cells in vitro. It has been suggested that our ability to predict effects at low doses will ultimately depend upon our ability to understand the mechanisms whereby certain phenomena arise. It is probable that the major contribution of in vitro studies will be in developing an undersianding of mechanisms

The three major effects of radistion which concerned this conference were: (I) loss of cell viability, (2) mutzoenesis and (3) curcinogenesis. In each of these areas in vitro assays or endpoints are available, and it is likely that these will be improved as the degree of knowledge obtained and requited is increased.

To date the major emphasis of in vitgo studjes has been on the loss of cell viability, usually after doses from one hundred to several thousand rads. As a result, a great deal of information has been oblained on the 
effects of radiation type, cell age, dose fractionation, sensitizing and protective agents, etc. The variations in survival response which result from changing any of the listed parameters make it possible to use correlation studies in the search for underlying mechanisms.

Since the subject of the conference wa offects at low dose, it was natural that the question of survival at low doses should be discussed. There is now little doubt, especially front studies with synchronized populations, that $X$-ray survival curves have a negative slope at low doses, and not the zero slope which is predicted by a simple application of the multitarget model of inactivation. The magnitude of this slope may, however, be extremely diffieult to determine.

To date, in vitro studies with mammalian cells have not greatly advanced our knowledge of either radiation-induced mutagenesis or carcinogenesis. However, as a result of recent technical advances it now seems possibke to use in vitro studies to investigate a variety of subjects concerned with both processes. Amongst these are:

(i) The nature of acute dose response curves

(2) The effects of varying dose rate and fractionation

(3) The effects of agents which might alter response

(4) Species, cell type and locus variations in sensitivily

(5) The possible synergistic roles of virus and radiation in carcinogenesis.

In vitro techniques are now available to investigate mutations involving drug resistance, auxotrophy and conditional lethality, both in the forward and backward direction. The data avgilable are extremely limited and apparently variable, and suggest that in addition to the variables, such as cell number at risk, expression time and drug levels, which have been tested, other factors play a major role in determining apparent mutation frequency. In addition, the nature of the apparent mutations produced has not been adequately investigated.

With respect to radiation-induced carcinogenesis, the possibility has been raised that this may require or be greatly facilitaled by co-factors, with viruses being the most likely cardidates.

\title{
Human Epidemiology
}

\section{FOLLOW-UP OF EXPOSED POPULATIONS}

\author{
G. W. Beete, M. L. Griem, and E. L. Saenger \\ National Academy of Sciences, The University of Chicago, \\ and Universtty of Cincinnati College of Medicine
}

Epidemiology will continue to be one of the most useful sources of information concerning effects of low doses in human beings. We oulline the various steps to be laken to generate further information on contributions from this approach.

]. Exposed populations possibly available for study.

A. Those in high background regions

B. Occupational workers including mililary personnel

C. Individuals irradiated for medical puposes

D. Atomic bomb survivors including Marshallese

of the exposed populations, the radiation workers, physicians, war reterans exposed to medical radiation, atomic bomb survivors and patients in prepaid medical programs would seem to be groutps amenable to simple follow-up.

II. Specific groups to be considered. These would include all groups in whom such studies are already uniler way.

A. Populations, for alteration in sex ratio

B. Fetuses irradiated during early pregnancy, for birth defects

C. Abnormalities in children receiving kigh gonadal doses, along with consideration of follow-ap in their offspring

D. Further consideration of correlation of cytogenetic abnormalities and subsequent development of disease. Improvement in aufomation of cytogenetic scoring is strongly urged.

III. Factors which must be considered in obtaining maximum usefuiness and economy in above and similar studies.

A. It is essential that the hypotheses to be tested and the research design be clearly stated prior to the start of 
dats collections

B. Sizes of samples need be specified

C. Good dosimetry is important. Qualitative studies (i.e. Iadistion vs. no radiation) should be considered less desirable

D. Quality of controls. Consideration of their appropriateness in regard to eligibility and similar ceiteria is important

E. Reasonabie cost estimates are required

F. Estimate of timo to assure successful completion is important, especially for long term observation

G. Access to Social Security records should be improved

H. Development of a National Death Index would be highly desirable.

IV. Theoretical and practical considerations relating human end animal investigalion

A. Mathematical treatment of dose-effect relations extrapolated to low doses shoutd be tntensified

B. Experimental studies of the shape of the dose-response curve at low dose and dose rates, and of mechanisms of cancer induction should be continued actively

C. Animal experiments comparing effects of same doses of ${ }^{13 L} \mathrm{I}$ and $\mathrm{X}$ rays, such as have been done for cell kiling and oncogenesis in the rat, should be continued.

\title{
EPIDEMIOLOGY OF ENVIRONMENTAL EFFECTS
}

\author{
P. E. Sartwell
}

\section{Johns Hopkins Schaol of Hyziene and Public Health}

The first speaker, Dt. Arthut Tamplin, offered the opinion that the re is an immediaze problem of setting radiation exposure limits; that there is increasing evidence of a linear doseffect relationship at low dose levels; and that the weighing of risks against benefits was not an acceptable method of provedure in determining health practices. He cited immunization against polionyelitis, in which he thought the prunciple was tor minimuze all risks. In the discussion it became clear that there was disagreement by a substantial number of participants with these views. It was pointed out that in the first latge-scale use of poliovaccine a considerable risk of adverse effects was taken, in recognition of the large antiespated benefis; and that unantıcipaled hazards did, in fact, appear. Another example of the weighing of risks against benefits was the decision, in the face of evidence that oral contraceptives produce thromboembolism, to continue to sanction their use, in view of thel superion efficacy, and the pJobability that adverse effects associated with pregnancy, delivery and illegal abortions would outweigh thejr hazards.

The question as to whal epidemiological approaches are promising was taised. Exposed groups on which longiludinal sludies can be made are of two chier sorts: occupationally exposed, and those who have received therapeutic or diagnostic radiation. Examples of the former are physicians, radium workers and uranium miners. Among the second class, it was suggested that luberculosis patients who had received pneumolhorax treatments (in connection with which fluoroscopy was practiced) shoujd be followed up. The case-control method of epidemiologic study was recommended as wholly satisfactory in appropriate circumstances. Further attempts to study populations living in certain areas of high background radiation were advised. Situations in which a group accidentally stastains an excessive exposure should be so dealt with that any consequences can te assured of detection oves a sufficiently long period. They should be under the cognizance of a governmental or quasi-gowernnental agency, although the observations might be made by some other team under contract. Cueation of a "National Environmental Effects Survejlance Center" was proposed.

An initial report was made on the pooled data from two groups of radiumexposed persons. Although the exposures occurred forty -odd years ago, it was surprising to learn that a large majority of the subjects aIe still alive, despite the heavy exposures which many of them sustajned. Malignancies have been divided irto those believed to be caused by radiation (osteosarcomas and carcinomas of the craniej sinuses and mastojd), and those not judged to be so caused. While estimation of accumulated dose from this type of exposure is difficult, no Jadiom-caused malignancies have been observed at estimated doses below 1000 rads. Approximately eight central nervous system tumors have been identified. Investigation of the children of exposed subjects will now be initiated.

Stveral equations representing dose-response relationships for the cancers judged radiation. related were tested for fit. The linear equation did not fit all the data sets; a,dost-squared exponential provided 
a better fit to one set of data.

It was observed that incidence of Jung cancer bears a roughly linear relation to number of cigareltes smoked, while skin cancer does nat show this simple relationship to beta radiation. When there ase Jelatively few subjects at low doses, it is difficult either to demonstrate, or rule out, linearity. The question of how differences in susceptibility in a nonhomogeneous population might affect the dose response curwe was discussed. .

The meaning of "doubling dose" was considered in terms of the stability of the base-line incidence of mutations or, as in this instance, of malignant disease. Two models were suggested: one which is linear throughout, and one which approaches linearity at low doses but becomes exponential above the doubling dose. According to the latter model, the estimate of the low-dose slope differs, depending on the dose range within which the estimates are made.

\section{Physics and Models}

\section{J. J. Broerse}

\section{Radlobialogical histitute, TNO}

The results of Bond. Shellabarger and Voged on the incidence of breast carcinoma $\mathrm{i}$. the rat after itradiation with $\mathrm{X}$ rays and fission neutons were discussed. It had been proposed originaly that both types of radiation yieid linear dose effect relationships. It was shown, however, that plotting the results on a log-log scale clearly indicates that the dose-effect curves, are nonlinear. From microdosimetry considerations, it an be inferred that the development of a tumor originates from more than one cell. The paper of Kelleret and Rossi on RBE and the primary mechanism of action was reported. The data in this paper indicate that the $\mathrm{X}$-tay cell survival curve has an initial non-zero slope, as was found earlier in the experiments of Barendsen, and Sinclair and Morton. The consequente of this initial slope for $X$-ray survival curves is that the RBE for high-LET radiation, e.g., kast neutjons, wil] not grow to infinity at low doses, but will have a maxirnum value. The importance of microdosimetry for an understanding of low-kevel effects has been clearly demonstrated.

The need for copperation in late effects regearch was stressed, since these studies require large-scale experiments and long-term commitments. The preliminary results of a dosimetry intercomparison within a group of European laboratories were presented.

The concept of the dose effectiveness function (DEF) was introduced. This sometimes can be approximated as the inverse of the RBE. A number of properties of the DEF over a large dose range wite described. A cytogenetic model is under development, which seems able to account for the DEF. The properties oi the DEF for various endpoints have to be studied in mote detail, since they promise to provide a basis for evaluating the parameters of low-dose effects on man. 
THIS PAGE

WAS INTENTIONALIY

LEFT BLANK 


\section{MEETING AS A COMMITTEE OF THE WHOLE}

A steering committe had been appointed by the Conference conveners to meet on the second evening and produce an ayenda for the plenary tommitee session. The chairman was M. Elkind, the secretery was S. Abrahamson, and members were M. Fry, C. Hollander, G. Silini, C. Edington, L. Hempelman, C. Mays, H. Rossi, G. Beebe and A. Tamplin. The committee reported back with the following recommendations:

I. the Proceedings of the Conference should be issued as an Argonne National Laboratory Repori;

2. an account of the Conference shoutd be prepared for publication in an appropriate journal;

3. there should be no attempt at this time to formalize the organization of this group, but instead,

4. the North American Late Effects Group should be asked to establish a continuing committee to have cognizance of research on low dose effects, and to recommend conferences or other actions as needed.

The group approved issuance of the Proceedings as an Argonne report, with the stipulation that it should include a summary of the Conference focused on identifying the importanl unresolved problems. It was agreed that this should be done by a team consisting of G. A. Sacher, W. K. Sinclair, and R. E. Rowland. The same team was instructed to produce the account of the Conference for publication in a scientific journal.

The group accepted the steering commiltee's recommendation about continuity and adopted a resolution recommending to the North American Late Effects Group that it accept a specific responsibility to form a subcommittee on the subject of low dose and low dose rate effects, which would keep informed of work in those areas and convene workshops on the subject when appropriate.

There was a brief discussion of the North American Late Effects Group and the European Late Effects Group as informal interest groups. The present role of NALEG is primarily communication, whereas ELEG is responding to a need in Europe for better international and interinstitutional cooperation on research programs, facilities and standards. The two groups are in close contact, and other regions of the world (e.g., Japan) are moving toward a similat pattern of organization. 
THIS PAGE

WAS INTENTIONALLY

LEFT BLANK 


\title{
OVERVIEW AND CRITIQUE OF THE CONFERENCE
}

\author{
W K. Sinclatr, R. E. Rowland, and G A Sacher
}

One of the recurrent themes in the commentares on both systerne and cellular effects is the suggestion that in vitro models and assay systems are poitenlially powerful tools for investigaling mechanisms of late and low.level radiation effects. Until a year or so ago this would have been litle more than a pious hope, but recent adrances in the deveiopment of in vitro assays for carcinogenesis give grounds for confidence that these methods will usher in a period of rapid progress in the study of cancer inductıon, just as the Puck cloning technique did for the assay of lethal effects in mammalan celts

Although these in utro systems deserve to be investigated wilh sil deliberate speed, our planning should lake account of the possibility that the induction of a neoplastic transformation by ionizing radiations in vitro wil be mose difficult than unduction by cherrueal agenls Accelerated research on promoling factors and the role of viruses may, therefore, have to precede and accompany investugation of the role of raduations per se We can enticipate that research on ionieng radiations in cancer induction will need to break new ground, because most of out knowledge of radiation effects in mammalian cells is based on cell killing as the endpoun and may nol apply to more subtle transitions in surviring cells. An important additional problem is that the tumorigenic ef ficacy of hugh-LET fast neutrons and alpha rays is not satisfactotdy explaned by presently accepted models, in yiew of the absence of teparr of damage by high-LET radiations, and of evidence that the whole chromosome complement is the geometrical target for cell killing

The inference that mofe than one cell is involved in the induction of mamnary cancer un tats, which was drawn from an analysis of the dose dependence for inductoon of mammary tumors by gamma rays and fast neutrons, deserves to be followed up, because it is critically important in relation to the estimation of tumor yields at very low doses Howeves, evidence was also presented that the life shortening in mice given lifetme gamma ray exposure changes from a multiple event (square of dely dose) to a sungle-event (first power) trend at low doses A simular transilion to fust-power dose dependence is observed in the kuling of mammalan cells in vitro by $X$ or gamma rays These findungs make it important to investigate the relation between the radiation-induced precancerous molecular lesions and the "spontaneous" lesions The extent to which they interact is umportant for cancer and aging research as well as for the study of low-level raduation effects

There was a consensus that increased understanding of mechanisms is perhaps the most effective way in which laboratory research can contribute to the detemintion of the effects of very low doses This does not diminish the unportance or necessily of large epudemıological studies, involving small or large animals, or retrospective studres in humans since these will continue to have an invaluable role in prowiding gutdance, imited though it may be, for the setting of exposure guidelines for a number of eritceally important occupational and medical exposure situations. The importance of these studies in the present state of our knowledge, whle we awat a more definitive understanding of mechanisms is obvious However, such large experumenis should also be designed and performed, so far as possible, to decide between hypolheses about mechanusins or to provide valud estumates of the basic biological and physcal parameters concerned with dose-ffect relationships

An important unanswered question in the modeling of human radiation effects which can be settled by experimental epdermology is whether the doubling dose assuinption emphasized by Gofman and Tamplin is the best first approximation for the estumation of expected tumor incidence This questron is stul moot after decades of aninal research, but it could probably be decided to an acceptabie level of precision by a critical reanslysis of the accumulated experimentsl data, published and unpublished, and, faling that, by a well-concerved experument

The valudation of models and estumation of parameters for the low-dose doman ean becompe excessuvely costly, and ewen faul completely, if theie is an injudicious choice of test system The laberatory mouse was a fortunate first chorce for epidemiolorical studies and continues to play a vital role in many late effects studies, but there is a growing awareness that some questions about Jow-dose effects can best be answered with longer.lived anumals An experiment with a relatively small number of dogs may perhaps be more cost-eftective than a large mouse experıment

These consideralions apply to the chouce of tadtation doses and qualities as well One necessary step for the validation of a mechansm deduced from an in vitro model is the demonstration that the celluiar and whole-anumal responses agree in absolute sensitwity, and in DEF and REE over a significant dose range

The survivors of a ceil population expoged to a dose of high-LET fast neutrons consist mostly of cells thal sustaned no damage in the target for lethality, whereas the survivors of a comparably effective gammarray 
dose are made up preponderantly of cells that sustaned damage and underwent repayr Wider explotiation of fast neutrons is, therefore, juslified by the possibulity of separalung repaur mechanisms from population recovery mechanisms and for providing a more relable extrapolation to effects at low doses.

The paramobint problem in the domaun of low-level effects is that of linear versus nonlunear response Evidence was heard on both sides of thus question, in respect to diverse endponts. The facl of nonlinear response is not un question, for all systerns studied thus far yield nonlenear responses in some part of the dose range, but it was reported that life shoztening and tumor incidence on the mouse make a transtion to a linear dose relationship at low doses The question is whether other, and perhaps all, endponts heve linear dose dependence in a finute dose interval above no dose Thus question can best be answered by the sequentud formulation and testing of hypotheses about the conditrons uniter which a lunear trend arises, and the formulation of these hypotheses wul be favored by frustful inleraction between systemic, eellular-molecular and microdosumetric research

The discessson of dose dependence during the Conterence was in fact two separate discussions, with little effort to achieve a unfied viewpount One discussion developed around exiemal radiations and endpoints such as life shortenung, tumors, mecrocataracts and chromosome aberrations, whule the other centered on internal emitters, with emphtasis on tumor incidence Thes lack of interchenge is nol a recent development, for the iwo areas have already developed divergent modes of analysis and mathematucal models There are practical teasons for these dufferences, stemmung from the great differences in sample sze between mouse and dog experiments, and from the special problems of dosimetry for internal entiters, but we nevertheless must not risk losing sight of the fact that all the work on external exposure and internal emitters must finally converge to a single consisient model. Some small fraction of the effort that goes into modeling these two domains of radiation effect should, therefore, be deroted to quanistative reconcilation of these models

The discussion of human epidemrology deali mostly with the follow up of defined exposed populations and with the problems of monitoring health, morbidsty and genelic parameters in the civl population These were covered in the posstion papers and Japporteur accounts Another important approach, not adequately represented in the discussion, is the epidemuological analysis of morbidity and mortality experience in the large population of industraal radiation workers in AEC or contractor installations The se people receive exposures within Jimits alkowed by FRC gudelines, and their radnation exposure histories are on record The stable employment pattern in the nuclear undustry for a period of a quarter century presents a favorable opportunity to evaluate the health status of this population relalive to the general population, and perhaps to test the predxctions of some contending models of low-level radation effects A follow-up study on the employees of some large AEC installations, entitled the AEC Health and Mortalıly Siudy, is now being conducted

There were two distinct kinds of proposals for monutoring the status of the entire civil population One was for systematic sampling of morbidity and mortality vanables together with a number of environmental and socioeconomic variables The other was for a mass scretring of newbouns for selected biochemical mutatrons These approaches should be examined further as two aspects of a sugle program, for the two kinds of measures are much more valuable of examined jointly

There was agreament anong most of the conferees that tisk benefil anslysis is an essenlial feature in the evaluation of hazards and the formulation of guidelines, and that the methodology of this process needs to be unvestugated and developed This view was coupled with an equally broaut agreement that discussion of this profound problem should be deferred unth a more competent panel can be astembled The convening of such a conference will be a challenging problem because of the wide span of biological, behavioral, ethical and political matters it must deal with

In overall evaluation, it can be said that the Conferente achieved its objective of bringing together for the first time representatives of the several disciplines that can contribute to solving the problem of low-level effects 1I can also be recognized, however, that the brief unitial discussions did not get beyond general consideration of some problems, and that cerlan aspects were not consudered at all The subject is so many-faceted that there is need for contunued examinalion of akvelopments in the several important areas and discussion of their Implications for the evolution of rational biological and social bases for gudelines Means should be found to foster thus kind of multudsciphuray unierchange, under whatever sponsorshup is deemed to be approprate 